\title{
Berry Phenolic Antioxidants - Implications for Human Health?
}

\author{
Beata Olas* \\ Department of General Biochemistry, Faculty of Biology and Environmental Protection, University of Lodz, Lodz, Poland
}

\section{OPEN ACCESS}

Edited by:

Claudio Bucolo,

Università degli Studi di Catania, Italy

Reviewed by:

Corrado Tringali,

Università degli Studi di Catania, Italy

David Auñón-Calles, SEPROX BIOTECH, Spain

*Correspondence:

Beata Olas

beata.olas@biol.uni.lodz.pl

Specialty section:

This article was submitted to Pharmaceutical Medicine and Outcomes Research,

a section of the journal

Frontiers in Pharmacology

Received: 14 October 2017

Accepted: 23 January 2018

Published: 26 March 2018

Citation:

Olas B (2018) Berry Phenolic

Antioxidants - Implications for Human Health? Front. Pharmacol. 9:78. doi: 10.3389/fphar.2018.00078
Antioxidants present in the diet may have a significant effect on the prophylaxis and progression of various diseases associated with oxidative stress. Berries contain a range of chemical compounds with antioxidant properties, including phenolic compounds. The aim of this review article is to provide an overview of the current knowledge of such phenolic antioxidants, and to discuss whether these compounds may always be natural gifts for human health, based on both in vitro and in vivo studies. It describes the antioxidant properties of fresh berries (including aronia berries, grapes, blueberries, sea buckthorn berries, strawberries and other berries) and their various products, especially juices and wines. Some papers report that these phenolic compounds may sometimes behave like prooxidants, and sometimes demonstrate both antioxidant and prooxidant activity, while others note they do not behave the same way in vitro and in vivo. However, no unwanted or toxic effects (i.e., chemical, hematological or urinary effect) have been associated with the consumption of berries or berry juices or other extracts, especially aronia berries and aronia products in vivo, and in vitro, which may suggest that the phenolic antioxidants found in berries are natural gifts for human health. However, the phenolic compound content of berries and berry products is not always well described, and further studies are required to determine the therapeutic doses of different berry products for use in future clinical studies. Moreover, further experiments are needed to understand the beneficial effects reported so far from the mechanistic point of view. Therefore, greater attention should be paid to the development of well-controlled and high-quality clinical studies in this area.

\section{Keywords: berries, phenolic compounds, antioxidants, health, oxidative stress}

\section{INTRODUCTION}

Natural phenolic compounds are found in many foods, including vegetables, fruits, tea, coffee, chocolate, wine, honey, and oil (Kulling and Rawel, 2008; Szajdek and Borowska, 2008; Chong et al., 2010; Chrubasik et al., 2010; Christaki, 2012; Kutlesa and Mrsic, 2016; Gomes-Rochette et al., 2016).

Recent years have seen increased consumption of berries, and fruit in general. Research suggests that this increased intake of fruits and berries may be associated with a reduced incidence of disorders induced by reactive oxygen species (ROS), including cardiovascular disorders, cancer and inflammatory processes (Gomes-Rochette et al., 2016). Berries and their products (i.e., berry juice and jam) are very often recognized as "superfoods." They possess high concentrations of phenolic compounds, which have been found in in vitro and in vivo studies to possess a range of biological activities, including anticancer and antiplatelet activities, as well as antioxidant 
properties (Valcheva-Kuzmanova et al., 2006; Erlund et al., 2008; Kulling and Rawel, 2008; Szajdek and Borowska, 2008; Chong et al., 2010; Chrubasik et al., 2010; Christaki, 2012; Giampieri et al., 2012, 2015; McEwen, 2014; Nile and Park, 2014; Del Bo et al., 2015; Skrovankova et al., 2015; Wightman and Henberger, 2015; Kristo et al., 2016; Olas, 2016, 2017). However, these compounds may not influence the levels of oxidative stress biomarkers, and may even have prooxidative effects. In addition, the precise biological activities of berry phenolics are dependent on a range of factors including the class of phenolics, their concentration, the type of berry and even the form consumed, be it fresh berries, juice, wine, jam, oil or medicinal products. This review article summarizes the current knowledge concerning whether the phenolic compounds within berries may always have a beneficial influence on human health as antioxidants, and to what extent these compounds may sometimes act as prooxidants. The source information for this paper is derived not only from in vitro models, but also in vivo models.

\section{THE BOTANICAL CLASSIFICATION OF BERRIES}

Although, according to botanical terminology, a berry is a simple fruit with seeds and pulp produced from the ovary of a single flower with a fleshy pericarp, the term "berry" is also commonly used to refer in general to a small, pulpy and often edible fruit. Blueberries may be categorized as berries under both definitions, but grapes are berries only according to the botanical definition. Moreover, while strawberries and blackberries are typically referred to as berries, they are not officially categorized as such (Hickey and King, 2001).

Berries belong to several families, although the two key examples are the Rosaceae, including black chokeberry (Aronia melanocarpa), strawberry (Fragaria ananassa), red raspberry (Rubus ideaus), black raspberry (Rubus occidentalis), blackberry (Rubus fruticosus) and cloudberry (Rubus chamaemorus), and the Ericaceae, including cranberry (Vaccinium macrocarpon), bilberry (Vaccinium myritillus), lowbush blueberry (Vaccinium angustifolium), highbush blueberry (Vaccinium corymbosum). Examples of berries from other families include blackcurrants (Ribes nigrum; family: Grossulariaceae), sea buckthorn (Elaaagnus rhamnoides (L.); family: Elaeagnaceae) and grapes (Vitis; family: Vitaceae).

\section{THE CHEMICAL COMPOSITION OF BERRIES}

A huge variety of phenolic compounds are produced by plants, with 1000s recognized throughout the plant kingdom. They can be found in various parts of the plant, but particularly the fruits, leaves and seeds, where they are typically involved in the defense against ultraviolet radiation and pathogens. Phenolics possess one or more aromatic rings bearing one or more hydroxyl groups. They occur in free and conjugated forms with acids, sugars, or other water-soluble or fat-soluble compounds
(Szajdek and Borowska, 2008; Nile and Park, 2014; Del Bo et al., 2015; Skrovankova et al., 2015).

For years, phenolic compounds were regarded as antinutritional compounds, and in some cases as toxic and mutagenic. Their anti-nutritional activities result from their interactions with proteins, which reduce nutrient assimilation by the inhibition of proteolytic, lipolytic and glycolytic enzymes. Moreover, metal cations are often made unobtainable by complexing with phenolic compounds in humans consuming a plant-based diet. It is important to note that the toxicity of phenolic compounds has not yet been fully recognized and was ignored for years (Bisson et al., 2015).

Berries are not only a source of non-nutritive compounds, including phenolics (Singh and Basu, 2102), but are also a rich source of wide variety of nutritive compounds, including sugars (glucose, fructose) and minerals (phosphorus, calcium, iron, potassium, magnesium, manganese, sodium and copper) (Kulling and Rawel, 2008; Szajdek and Borowska, 2008; Giampieri et al., 2012; Del Bo et al., 2015; Malinowska and Olas, 2016). In addition, iron and manganese are important components of antioxidant enzymes. Berries contain a large amount of the vitamins $\mathrm{A}, \mathrm{C}$ and $\mathrm{E}$, which act as antioxidants and may reduce the inflammation process (Skrovankova et al., 2015). Blackcurrants and sea buckthorn berries have particularly high concentrations of vitamin C, ranging from 120 to $215 \mathrm{mg}$ per $100 \mathrm{~g}$ fruit for blackcurrants, and as high as $600 \mathrm{mg}$ per $100 \mathrm{~g}$ fruit for sea buckthorn berries (Olas, 2016; Malinowska and Olas, 2016). Furthermore, berries contain low concentrations of lipids but high concentrations of dietary fiber, which has a nutritional function and reduces the level of low density lipoprotein (LDL) in serum. In addition, it is notable that sea buckthorn oil (extracted from seeds and fruits) and grape seed oil are rich source of fatty acids, unsaturated fatty acids in particular, which have beneficial effects on cardiovascular diseases, neurodegenerative diseases and cancer (Olas, 2016). All these compounds together have a synergistic and multifunctional effect on human health. The chemical composition of a particular berry depends on a range of factors, such as cultivar and variety, plant nutrition, time of harvest, growing location and environmental conditions (Skrovankova et al., 2015).

\section{THE CHEMICAL STRUCTURE OF PHENOLIC COMPOUNDS WITH ANTIOXIDANT PROPERTIES}

\section{Anthocyanins}

Anthocyanins confer the blue, purple and red color of many fruits, including berries. However, berry anthocyanins are not only responsible for fruit color, but also may be used as natural pigments for the food industry (He and Giusti, 2009; Lee et al., 2015). In addition, anthocyanins are known to be one of the most powerful natural antioxidants. Berries are one of the richest sources of anthocyanins among all the fruits ( $\mathrm{He}$ and Giusti, 2009; You et al., 2011; Lee et al., 2015; Olivas-Aguirre et al., 2016) and are found at the highest concentrations in 
the skins of berries. Anthocyanins consist of an aromatic ring bonded to a heterocyclic ring containing oxygen, which is also bonded by a carbon-carbon bond to a third aromatic ring. They can be classified into six forms based on the presence of hydroxyl and methoxyl substitutions on the B-ring: cyanidin, malvidin, peonidin, petunidin, pelargonidin and delphinidin (He and Giusti, 2009). The most common types of anthocyanins present in various berries are given in Table $\mathbf{1}$.

An important property of anthocyanins is that they are able to cross the blood-brain barrier (Andres-Lacueva et al., 2005; Kalt et al., 2008). However, they also have low bioavailability compared with other phenolic compounds (Manach et al., 2004, 2005; Talavera et al., 2006).

Lee et al. (2015) note that the total antioxidant capacity of berries rich in distinct anthocyanins is derived from both anthocyanin composition and the antioxidant capacity of individual anthocyanins.

\section{Other Phenolic Compounds}

A wide range of other secondary compounds are also available in different types of berries. Strawberries, blueberries and chokeberries are rich sources of flavon-3-ols, while red raspberries and cloudberries provide high levels of such tannins as ellagitannins. In addition, berries are good sources of such phenolic acids as ellagic acid, chlorogenic acid and gallic acid: blueberry, for example, contains up to $2 \mathrm{~g} / \mathrm{kg}$ FW of chlorogenic acid (Romani et al., 2016). The absorbance rate varies depending on the type of acid, with chlorogenic acid being poorly absorbed, and gallic acid rapidly absorbed. Ellagic acid represents about $50 \%$ of the total phenolic compounds in cranberries and raspberries (Nile and Park, 2014; Skrovankova et al., 2015). In addition, both grapes and red currants are rich in resveratrol, which belongs to the group of stilbenes.

Table 2 presents the total concentrations of phenolic compounds, including anthocyanins, in various berries and berry products. For example, the concentration of phenolic compounds in aronia is about $2080 \mathrm{mg} / 100 \mathrm{~g}$ fruits, which is higher than other berries (for blackberries is about $248 \mathrm{mg} / 100 \mathrm{~g}$ fruits and for blueberries is about $525 \mathrm{mg} / 100 \mathrm{~g}$ fruits) (Lee et al., 2015). Industrial berry products such as aronia berry juice have also a high concentration of phenolic compounds (Table 2). However, only a few commercial products derived from berries (e.g., Aronox $^{\circledR}$ aronia berry extract by Agropharm, Poland), have welldocumented chemical compositions and biological activities, including antioxidant properties (Olas et al., 2008; Lee et al., 2015; Daskalova et al., 2015) (Table 2). Aronia berries and aronia juice are believed to possess the highest antioxidant capacity of all studied berries and their juices (Table 3).

Other authors have reported that berry seeds may be a source of phenolic compounds: grape seeds were found to contain various phenolic acids including gallic acid, p-qumaric acid and ferulic acid (Nassiri-Asl and Hosseinzadeh, 2016). Duba and Fiori (2015) and Garavaglia et al. (2016) have also reported a large amount of phenolic acids, flavonoids, tannins and stilbenes in grape seed oil, with the main phenolic components being epicatechins, catechins, procyanidins and resveratrol (Garavaglia et al., 2016). The total amounts of phenolic compounds extracted from grape seed oil by cold-pressing is about $2.9 \mathrm{mg} / \mathrm{kg}$; this amount includes small amounts of resveratrol $(0.3 \mathrm{mg} / \mathrm{kg})$, catechin and epicatechin (1.3 mg/kg each) (Garavaglia et al., 2016). Another source of phenolic compounds, including the flavonoids rutin and quercetin, is sea buckthorn oil extracted from the berry pulp and seeds (Olas, 2016). Many phenolic compounds are found in the small seeds on the outside of strawberries; their antioxidant value is about $14 \%$ of the entire value of the fruit.

Similar bioactive compounds, including phenolic compounds, are found in berries and berry leaves, i.e., fresh and dried leaves of sea buckthorn have different anthocyanins and flavonoids, such as gallocatechin and epicatechin (Christaki, 2012; Olas, 2016; Ferlemi and Lamari, 2016). Berry leaves are one of the richest sources of chlorogenic acid (Ferlemi and Lamari, 2016).

\section{METABOLISM AND BIOAVAILABILITY OF PHENOLIC COMPOUNDS}

Berries are an integral part of the human diet, both as fresh berries and as various products, such as jams, juices, wines and berry extracts, which may act as functional foods. They also have a pleasant taste and little calorific content. In addition, both fresh berries and their products have high concentrations of phenolic compounds: flavonoids such as anthocyanins, and nonflavonoids such as stilbenes and phenolic acids. As berries are very often consumed raw, these compounds are not deactivated by cooking. About 8000 phenolic compounds are known to be present in the modern human diet (Ogah et al., 2014; Lall et al., 2015; Del Bo et al., 2015; Terahara, 2015; Kristo et al., 2016).

From the nutritional point of view, phenolic compounds are xenobiotics, which are metabolized in the digestive system as in a "normal dietary situation" (Gheribi, 2011; Bisson et al., 2015). Phenolic compounds are metabolized to sulfated compounds and methylated compounds, and are glucuronidated in the liver. An important metabolite formed from phenolic compounds following the consumption of fruits such as berries is hippuric acid (Toromanovic et al., 2008; Del Bo et al., 2015; Santhakumar et al., 2015).

The Recommended Daily Intake for phenolic compounds remains unknown and given the range of various biological effects occurring at different concentrations, it may well be impossible to determine a uniform value (Gheribi, 2011).

Recently, various in vitro and in vivo experiments have demonstrated that phenolic compounds have a range of beneficial properties including anticancer, anti-platelet, anti-inflammatory and antioxidant effects (Valcheva-Kuzmanova et al., 2006; Erlund et al., 2008; Kulling and Rawel, 2008; Szajdek and Borowska, 2008; Chong et al., 2010; Chrubasik et al., 2010; Christaki, 2012; Giampieri et al., 2012, 2015; McEwen, 2014; Nile and Park, 2014; Del Bo et al., 2015; Skrovankova et al., 2015; Wightman and Henberger, 2015; Kristo et al., 2016; Olas, 2016, 2017; Umeno et al., 2016). Not only does the concentration of phenolic compounds have an effect on human health, but also their metabolism and bioavailability (Yang et al., 2011; Wilczak et al., 2013). 
TABLE 1 | Major types of anthocyanins, which are presented in various berries (Lee et al., 2015; Nayak et al., 2015; Wang et al., 2015; Kristo et al., 2016; Kšonžeková et al., 2016; Samoticha et al., 2017; modified).

\begin{tabular}{|c|c|c|c|c|c|c|}
\hline Berries & \multicolumn{6}{|c|}{ Type of anthocyanins } \\
\hline $\begin{array}{l}\text { Aronia berries } \\
\text { (Aronia } \\
\text { melanocarpa) }\end{array}$ & & $\begin{array}{l}+ \\
\text { (major - cyaniding } \\
\text { 3-galactoside, } \\
\text { cyaniding } \\
\text { 3-arabinoside; minor - } \\
\text { cyaniding 3-glucoside; } \\
\text { cyaniding 3-xyloside) }\end{array}$ & & & & \\
\hline $\begin{array}{l}\text { Bilberries } \\
\text { (Vaccinium } \\
\text { myritillus) }\end{array}$ & & $\begin{array}{l}+ \\
\text { (major - } \\
\text { cyanidin-3-galactoside; } \\
\text { minor - cyanidin } \\
\text { glucoside; cyanidin } \\
\text { arabinoside) }\end{array}$ & $\begin{array}{l}+ \\
\text { (minor - delphinidin } \\
\text { arabinoside; } \\
\text { delphinodin } \\
\text { galactoside; delphinidin } \\
\text { glucoside) }\end{array}$ & $\begin{array}{l}+ \\
\text { (minor - peonidin } \\
\text { glucoside) }\end{array}$ & $\begin{array}{l}+ \\
\text { (minor - malvidin } \\
\text { galactoside; malvidin } \\
\text { arabinoside) }\end{array}$ & $\begin{array}{l}+ \\
\text { (minor - petunidin } \\
\text { glucoside) }\end{array}$ \\
\hline $\begin{array}{l}\text { Blackberries } \\
\text { (Rubus } \\
\text { fruticosus) }\end{array}$ & & $\begin{array}{l}+ \\
\text { (major - } \\
\text { cyanidin-3-glucoside; } \\
\text { minor - } \\
\text { cyanidin-3-rutinoside, } \\
\text { cyanidin-3- } \\
\text { dioxalylglucoside, } \\
\text { cyanidin-3-xyloside; } \\
\text { cyanidin-3- } \\
\text { malonylglucoside) }\end{array}$ & & & & \\
\hline $\begin{array}{l}\text { Blueberries } \\
\text { (Vaccinium } \\
\text { corymbosum) }\end{array}$ & & $\begin{array}{l}+ \\
\text { (major - cyaniding } \\
\text { 3-galactoside; minor - } \\
\text { cyaniding 3-glucoside, } \\
\text { cyaniding } \\
\text { 3-arabinoside) }\end{array}$ & $\begin{array}{l}+ \\
\text { (major-delphinidin } \\
\text { 3-galactoside, } \\
\text { delphinidin } \\
\text { 3-arabinoside; minor - } \\
\text { delphinidin 3-glucoside) }\end{array}$ & $\begin{array}{l}+ \\
\text { (minor - peonidin } \\
\text { 3-galactoside, } \\
\text { peonidin } \\
\text { 3-arabinoside) }\end{array}$ & $\begin{array}{l}+ \\
\text { (major - malvidin } \\
\text { 3-galactoside, } \\
\text { malvidin } \\
\text { 3-arabinoside; } \\
\text { minor - malvidin } \\
\text { 3-glucoside) }\end{array}$ & $\begin{array}{l}+ \\
\text { (major - petunidin } \\
\text { 3-galactoside, } \\
\text { petunidin } \\
\text { 3-arabinoside; } \\
\text { minor - petunidin } \\
\text { 3-glucoside) }\end{array}$ \\
\hline $\begin{array}{l}\text { Elderberries } \\
\text { (Sambucus } \\
\text { nigra) }\end{array}$ & & $\begin{array}{l}+ \\
\text { (major - cyanidin-3- } \\
\text { sambubioside; } \\
\text { minor-cyanidin-3- } \\
\text { glucoside, cyanidin } \\
\text { 3,5-diglucoside, } \\
\text { cyanidin-3- } \\
\text { sambubioside-5- } \\
\text { glucoside) }\end{array}$ & & & & \\
\hline Grapes (Vitis) & + & + & + & + & + & + \\
\hline $\begin{array}{l}\text { Raspberries } \\
\text { (Rubus idaeus) }\end{array}$ & & + & & & & \\
\hline $\begin{array}{l}\text { Strawberries } \\
\text { (Fragaria } \\
\text { annassa) }\end{array}$ & $\begin{array}{l}+ \\
\text { (major - pelargonidin- } \\
\text { 3-glucoseide) }\end{array}$ & $\begin{array}{l}+ \\
\text { (minor - } \\
\text { cyanidin-3-glucoside) }\end{array}$ & & & & \\
\hline
\end{tabular}

Regular consumption of darker-colored berries, such as blackberries, blueberries, strawberries, raspberries and aronia berries, may provide a high intake of anthocyanin. For example, anthocyanins constitute about $30 \%$ of all phenolic compounds in blackcurrants and about 70\% in blueberries. However, plasma concentrations of anthocyanins are typically quite low due to 
TABLE 2 | The concentration of total phenolic compounds and anthocyanins in different berries and their products (Olas et al., 2008; Daskalova et al., 2015; Lee et al., 2015).

\begin{tabular}{|c|c|c|}
\hline Berries and their products & Phenolic compounds & Anthocyanins \\
\hline Aronia (Aronia melanocarpa) berries & $2080 \mathrm{mg} / 100 \mathrm{~g}$ fruits & $\begin{array}{l}240 \mathrm{mg} / 100 \mathrm{~g} \text { fruits (frozen) } \\
280 \mathrm{mg} / 100 \mathrm{~g} \text { fruits (dried) }\end{array}$ \\
\hline Aronia (Aronia melanocarpa) berry extract (Aronox ${ }^{\circledR}$ by Agropharm, Poland) & $309.6 \mathrm{mg} / \mathrm{g}$ of extract & $110.7 \mathrm{mg} / \mathrm{g}$ of extract \\
\hline Aronia (Aronia melanocarpa) berry juice (Vitanea Ltd., Plodvir, Bulgaria) & $4772.2 \mathrm{mg} / \mathrm{l}$ & $3529.1 \mathrm{mg} / \mathrm{l}$ \\
\hline Bilberries (Vaccinium myritillus) & $181-585 \mathrm{mg} / 100 \mathrm{~g}$ fruits & \\
\hline Blackberries (Rubus fruticosus) & $248 \mathrm{mg} / 100 \mathrm{~g}$ fruits & $949.4 \mathrm{mg} / 100 \mathrm{~g} \mathrm{dw}$ \\
\hline Blueberries (Vaccinium corymbosum) & $525 \mathrm{mg} / 100 \mathrm{~g}$ fruits & $1562.2 \mathrm{mg} / 100 \mathrm{~g} \mathrm{dw}$ \\
\hline Blackcurrants (Ribes nigrum) & $560 \mathrm{mg} / 100$ fruits & $1741.6 \mathrm{mg} / 100 \mathrm{~g} \mathrm{dw}$ \\
\hline Cranberries (Vaccinium macrocarpon) & $120-315 \mathrm{mg} / 100 \mathrm{~g}$ fruits & \\
\hline Grape (Vitis) seed extract (by Bionorica, Germany) & $500 \mathrm{mg} / \mathrm{g}$ of extract & \\
\hline Red wines & $1000-4000 \mathrm{mg} / \mathrm{l}$ & $2.8 \mathrm{mg} / \mathrm{l}$ \\
\hline White wines & about 250 mg/l & \\
\hline Raspberries (Rubus idaeus) & $126 \mathrm{mg} / 100 \mathrm{~g}$ fruits & \\
\hline Sea buckthorn (Elaeagnus rhamnoides L.) berries & $260-490 \mathrm{mg} / 100 \mathrm{~g} \mathrm{FW}$ & \\
\hline Strawberries (Fragaria annassa) & $225 \mathrm{mg} / 100 \mathrm{~g}$ fruits & $60-80 \mathrm{~g}$ per $100 \mathrm{~g} \mathrm{FW}$ \\
\hline
\end{tabular}

TABLE 3 | Antioxidant capacity [measured by oxygen radical absorbing capacity (ORAC) or by Trolox equivalent capacity (TEAC)] of various fresh berries and berry juice [Kulling and Rawel, 2008; modified].

\begin{tabular}{lc}
\hline Berries & ORAC $(\boldsymbol{\mu}$ mol of Trolox equivalents/gram fresh weight) \\
\hline Aronia berries & $159.2 \pm 1.0$ \\
Blackberries & $55.7 \pm 14.7$ \\
Blackcurrants & $56.7 \pm 13.5$ \\
Strawberries & $20.6 \pm 2.3$ \\
Cranberries & $10.4 \pm 1.9$ \\
Red grapes & $7.4 \pm 0.5$ \\
White grape & $4.5 \pm 1.9$ \\
\hline Berry juices & TEAC $(\boldsymbol{\mu \mathbf { m o l } / \mathbf { m l } )}$ \\
\hline Aronia juice & $65-70$ \\
Blueberry juice & $13.3-17.1$ \\
Cranberry juice & $6.7-14.8$ \\
\hline
\end{tabular}

their poor absorbance profile (<1\%) (Fang, 2014a,b, 2015). The average total intake of these compounds is about $200 \mathrm{mg} /$ day and their concentration ranges from 10 to $50 \mathrm{nM}$ in plasma following the consumption of berries. In addition, human experiments have found $0.1 \%$ of anthocyanin intake to be excreted in urine. Fang $(2014 a, b)$ suggest that the apparent low bioavailability of some anthocyanins may be due to extensive presystemic metabolism rather than poor absorption. Xie et al. (2016) also indicate that the anthocyanins in aronia extract, constituting $34 \%$ of the total phenolic content, are extensively metabolized.

Studies have shown that the bioavailability of phenolic compounds differs from berry to berry, and this can also be affected by the method of processing (Scalbert and Williamson, 2000; McGhie and Alton, 2007; Del Bo et al., 2012; Kuntz et al., 2015). Food processing procedures, such as high-temperature treatments, are recognized as one of the major factors responsible for the destruction or modification of natural phytochemicals, which may in turn affect the antioxidant properties of foods
(Nicoli et al., 1999; Nayak et al., 2015). However, this reduction could be compensated for by the degradation of higher molecular weight phenolic compounds to smaller ones with greater antioxidant properties (Nayak et al., 2015).

In a study of the phenolic profiles of 26 berry samples and their antioxidant activity, Kahkonen et al. (2001) report that the choice of extraction method significantly affected both phenolic composition and antioxidant property of the resulting product. However, statistical analysis found no significant relationship between the observed activity and the contents of individual phenolic compounds.

Several factors, including the technological procedures used in winemaking, can also qualitatively and quantitatively affect the phenolic compound composition of wine (Garrido and Borges, 2013; Lingua et al., 2016). Phenolic compounds are transferred from the grape into the wine during crushing, maceration and fermentation. The majority of phenolic compounds in grapes are present in the skin and seeds (Lingua et al., 2016). Lingua et al. (2016) report a high correlation between phenolic composition and antioxidant capacity, with anthocyanins offering the greatest contribution to antioxidant capacity.

Berries are often consumed as fresh fruit, and in this form, their antioxidant capacity is not reduced by any factors such as heat or oxidation during processing (Patras et al., 2010; Skrovankova et al., 2015). It is very important to retain the beneficial properties of antioxidants in processed food products (Nayak et al., 2015). In the last decade, some papers have examined the influence of processing operations, such as drying or dehydration, on phytochemicals in fruit, including those of berries: for example, the flavonoid content of frozen aronia berries is $12.2 \mathrm{mg} / 100 \mathrm{~g}$ fruit, and of dried aronia berries is $107 \mathrm{mg} / 100 \mathrm{~g}$ fruit. Recently, Oszmianski and Lachowicz (2016) found the phenolics in dried aronia berry pomace and in juice obtained from crushed berries to have higher activity than those from the whole foods.

Freshly produced strawberry juices have higher anthocyanin concentrations than those stored for 6 months at $4^{\circ} \mathrm{C}$ and 
$30^{\circ} \mathrm{C}$ (Oszmianski and Wojdylo, 2009; Skrovankova et al., 2015). Moreover, a number of phenolic compounds in clear strawberry juices were found to be have been lost during processing (Skrovankova et al., 2015). After heat processing and drying, the total phenolic compound concentration is also less than $70 \%$ (Rudy et al., 2015; Skrovankova et al., 2015). Interestingly, the concentration of anthocyanins in raspberry juice may increase about 2.5 -fold after a week of storage at $20^{\circ} \mathrm{C}$ (Kalt et al., 1999; Skrovankova et al., 2015); however, in canned blackberries, significant amounts of anthocyanins are leached into the brine during processing and storage (Hager et al., 2008; Skrovankova et al., 2015). Elsewhere, anthocyanin concentration was found to decrease by about $30 \%$ in blueberries following thermal treatment (Giovanelli et al., 2013; Skrovankova et al., 2015). However, a 7\% increase in anthocyanin concentration was found in blueberries following blanching at $85^{\circ} \mathrm{C}$ for $3 \mathrm{~min}$ (Giovanelli et al., 2012; Skrovankova et al., 2015); in addition, a study of anthocyanin absorption following the consumption of one portion ( $300 \mathrm{~g})$ of minimally processed blueberry puree obtained from blanched or unblanched berries by Del Bo et al. (2012) found blanching to have no significant effect on total anthocyanin content, but in fact enhanced their absorption from minimally processed purees.

In addition, the concentration of berry phenolic compounds may change during berry development. The phenolics content of strawberries is known to decrease significantly by about $90 \%$ during ripening from green to red berries (Regonold et al., 2010; Crecente-Campo et al., 2012; Skrovankova et al., 2015).

\section{THE OXIDATIVE STRESS AND ITS BIOMARKERS; THE ROLE OF BERRY PHENOLIC COMPOUNDS IN THE OXIDATIVE STRESS}

In a healthy organism, the generation of reactive oxygen species is balanced by the activities of antioxidants (Bartosz and SadowskaBartosz, 2015). Increased ROS generation or diminished antioxidant defense is referred to as oxidative stress, which may participate in the development of various diseases, including cancer, cardiovascular diseases and neurodegenerative disorders (Bartosz and Sadowska-Bartosz, 2015). Oxidative stress is usually a local event, one which may be indicated by different biomarkers, including such markers of lipid oxidative modification as malondialdehyde $(\mathrm{MDA})$, conjugated dienes or $\mathrm{F}_{2}$-isoprostanes, markers of protein modification including carbonylated proteins, oxidation of thiol groups, protein fragmentation and nitrated proteins, or markers of oxidative damage of nucleic acids (Bartosz and Sadowska-Bartosz, 2015). These biomarkers not only have diagnostic value, but they may be also useful indicators of the need for antioxidant supplementation.

Various medicinal effects of berries against diseases associated with oxidative stress have been attributed to their high phenolic antioxidant content, especially anthocyanins and phenolic acids. In addition, berries are recognized to have high levels of vitamins A, C and E, which may act as antioxidants (Skrovankova et al.,
2015; Olas, 2016). Various authors have attributed the health benefits of whole foods to complex mixtures of phytochemicals (i.e., phenolics). Moreover, greater beneficial effects have been associated with the antioxidants obtained from whole foods than those obtained singly (Eberhardt et al., 2000; Nayak et al., 2015).

A number of in vitro and in vivo studies have examined the antioxidant activities of berries and their products, especially berry juices (Table 4). They have examined inter alia the inhibition of lipid peroxidation, inhibition of protein carbonylation, inhibition of ROS generation, increase of total antioxidant status and the increase of antioxidant enzyme activity. The results of these studies are given in Table 4. It is important to note that antioxidant effects were not only found in in vitro models or in animals, but also in humans, where dietary supplementation with a range of berry products, including berry juices, reduces the levels of a number of biomarkers of oxidative stress.

Previous studies have demonstrated that the consumption of berries rich in antioxidant phenolic compounds results in an increase in plasma total antioxidant status in humans (Wilson and Bauer, 2009; Negi et al., 2013; Kardum et al., 2014; Del Bo et al., 2015). The modulation of various antioxidant/prooxidant status markers observed in healthy subjects demonstrates the potential prophylactic actions of fresh berries and their products, and underlines their importance as part of an optimal diet. These benefits have also been observed in subjects with poor health, including patients with diseases which are very often correlated with oxidative stress, i.e., patients with cancer, metabolic syndrome or cardiovascular diseases (Table 4). ZafraStone et al. (2007) note that a combination of six berry extracts (wild blueberry, wild bilberry, cranberry, elderberry, raspberry seed and strawberry) exhibited significantly superior antioxidant potential than the consumption of individual berries.

However, some papers note that phenolic compounds may behave like prooxidants under conditions that favor autooxidation, such as high $\mathrm{pH}$ and in the presence of high concentrations of transition metal ions and oxygen molecules (Cotoras et al., 2014). Moreover, while small phenolic compounds (i.e., quercetin and gallic acid) are easily oxidized and possess prooxidant properties, phenolic compounds of high molecular weights (i.e., condensed and hydrolysable tannins) have little or no prooxidant properties (Hagerman et al., 1998; Cotoras et al., 2014). In addition, phenolic compounds such as vanillic acid, ellagic acid, gallic acid and rutin have been reported to possess dual antioxidant and prooxidant properties (Fukumoto and Mazza, 2000). Cotoras et al. (2014) found that grape extracts demonstrated antioxidant or prooxidant properties depending on the method of extraction and the variety of the grape. It is very important that the potential antioxidant function of a plant extract with phenolic compounds in vivo cannot be safely correlated from in vitro experiments, because they do not take into account the metabolic transformations and interactions that are known to affect the bioavailability and biological properties of phenolic compounds (Veskouis et al., 2012).

Veskouis et al. (2012) report the presence of such dual effects of a phenol-rich extract of grape pomace in in vitro 
TABLE 4 | The effect of different berries on the level of various biomarkers of oxidative stress.

\section{Berries Different biomarkers of oxidative stress}

In vitro experiments

Aronia Inhibition of ROS generation (antioxidant activity)

berries Model of hyperhomocysteinemia, human blood platelets, concentration of Aronox (containing phenolic compounds: $309.8 \mathrm{mg} / \mathrm{g}$ of extract): $2.5-10 \mu \mathrm{g} / \mathrm{ml}$ (Malinowska et al., 2013)

Human blood platelets, healthy subjects, concentration of Aronox (containing phenolic compounds: 309.8 mg/g of extract): 5-50 $\mu \mathrm{g} / \mathrm{ml}$ (Olas et al., 2008)

Human blood platelets, patients with cardiovascular risk factors, concentration of Aronox (containing phenolic compounds: $309.8 \mathrm{mg} / \mathrm{g}$ of extract):

$1-100 \mu \mathrm{g} / \mathrm{ml}$ (Ryszawa et al., 2006)

Human blood platelets, healthy subjects, patients with invasive breast cancer (before/after surgery and after I - IV phase of chemotherapy) and patients with

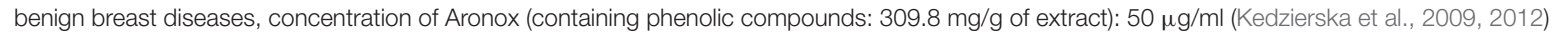

No effect on ROS generation (antioxidant/prooxidative properties - ?)

Human blood platelets, healthy subjects, concentration of Aronox (containing phenolic compounds: $309.8 \mathrm{mg} / \mathrm{g}$ of extract): 1-100 $\mu \mathrm{g} / \mathrm{ml}$ (Ryszawa et al., 2006)

Inhibition of protein carbonylation (antioxidant activity)

Human plasma, healthy subjects, patients with invasive breast cancer (before/after surgery and after I - IV phase of chemotherapy), concentration of Aronox (containing phenolic compounds: $309.8 \mathrm{mg} / \mathrm{g}$ of extract): $50 \mu \mathrm{g} / \mathrm{ml}$ (Kȩdzierska et al., 2013b)

No effect on protein carbonylation (antioxidant/prooxidative properties - ?)

Human blood platelets, healthy subjects, patients with benign breast diseases, patients with invasive breast cancer, concentration of Aronox (containing phenolic compounds: $309.8 \mathrm{mg} / \mathrm{g}$ of extract): 50 $\mu \mathrm{g} / \mathrm{ml}$ (Kȩdzierska et al., 2010)

Inhibition of protein nitration (antioxidant activity)

Human plasma, healthy subjects, patients with invasive breast cancer (before/after surgery and after I - IV phase of chemotherapy), concentration of Aronox (containing phenolic compounds: $309.8 \mathrm{mg} / \mathrm{g}$ of extract): $50 \mu \mathrm{g} / \mathrm{ml}$ (Kędzierska et al., 2013b)

Human blood platelets, healthy subjects, patients with benign breast diseases, patients with invasive breast cancer, concentration of Aronox (containing phenolic compounds: $309.8 \mathrm{mg} / \mathrm{g}$ of extract): 50 $\mu \mathrm{g} / \mathrm{ml}$ (Kẹdzierska et al., 2010)

Inhibition of lipid peroxidation (antioxidant activity)

Human plasma, healthy subjects, patients with invasive breast cancer (before/after surgery and after I - IV phase of chemotherapy), concentration of Aronox (containing phenolic compounds: $309.8 \mathrm{mg} / \mathrm{g}$ of extract): $50 \mu \mathrm{g} / \mathrm{ml}$ (Kȩdzierska et al., 2013b)

Rat hepatocytes treated with carbon tetrachloride and tert-butyl hydroperoxide, aronia juice (phenolic compounds: $546.1 \mathrm{mg}$ as GAE/100 ml): 5-100 $\mu \mathrm{g} / \mathrm{ml}$ (Kondeva-Burdina et al., 2015)

Increase of total antioxidant status (antioxidant activity)

Human plasma, healthy subjects, patients with invasive breast cancer (before/after surgery and after I - IV phase of chemotherapy), concentration of Aronox (containing phenolic compounds: $309.8 \mathrm{mg} / \mathrm{g}$ of extract): 50 $\mu \mathrm{g} / \mathrm{ml}$ (Kȩdzierska et al., 2013b)

Increase of thiols (antioxidant activity)

Human plasma, healthy subjects, patients with invasive breast cancer (before/after surgery and after I - IV phase of chemotherapy) and patients with benign

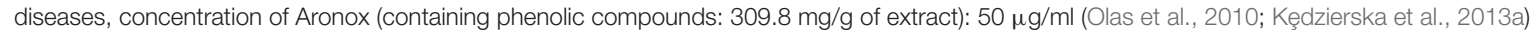

Rat hepatocytes treated with carbon tetrachloride and tert-butyl hydroperoxide, aronia juice (phenolic compounds: $546.1 \mathrm{mg}$ as GAE/100 ml): 5-100 $\mu \mathrm{g} / \mathrm{ml}$ (Kondeva-Burdina et al., 2015)

Human blood platelets, healthy subjects, patients with benign breast diseases, patients with invasive breast cancer, concentration of Aronox (containing phenolic compounds: $309.8 \mathrm{mg} / \mathrm{g}$ of extract): 50 $\mu \mathrm{g} / \mathrm{ml}$ (Kẹdzierska et al., 2010)

Increase of activity of antioxidant enzymes (catalase, glutathione peroxidase, superoxide dismutase) (antioxidant activity)

Human blood platelets, healthy subjects, concentration of Aronox (containing phenolic compounds: $309.8 \mathrm{mg} / \mathrm{g}$ of extract): 5 - 100 $\mu \mathrm{g} / \mathrm{ml}$ (Kẹdzierska et al., 2011)

Grapes Inhibition of ROS generation (antioxidant activity)

Model of hyperhomocysteinemia in vitro, human blood platelets, concentration of the phenolic fraction of seed (containing phenolic compounds: 500 mg/g of extract): $2.5-10 \mu \mathrm{g} / \mathrm{ml}$ (Malinowska et al., 2013)

Human blood platelets, healthy subjects, concentration of the phenolic fraction of seed (containing phenolic compounds: 500 mg/g of extract):

$1.25-50 \mu \mathrm{g} / \mathrm{ml}$ (Olas et al., 2008, 2012)

Inhibition of lipid peroxidation (antioxidant activity)

Rat hepatocytes treated with adriomycin, extract of phenolic compounds from defatted milled grape seeds: 2.5 - $25 \mu \mathrm{g} / \mathrm{ml}$ (Valls-Belles et al., 2006$)$

Swine erythrocytes, extract from grape seeds (over 90\% condensed tannins): $7.5-30 \mu \mathrm{g} / \mathrm{ml}$ (Olchowik et al., 2012)

Bovine spermatozoa, polyphenolic-rich grape pomace extract: 1-5 $\mu \mathrm{g} / \mathrm{ml}$ (Saponidou et al., 2014)

Inhibition of protein carbonylation (antioxidant activity)

Rat hepatocytes treated with adriomycin, extract of phenolic compounds from defatted milled grape seeds: 2.5 - $25 \mu \mathrm{g} / \mathrm{ml}$ (Valls-Belles et al., 2006$)$ Increase of thiols (antioxidant activity)

Human blood platelets, healthy subjects, concentration of the phenolic fraction of seed (containing phenolic compounds: $500 \mathrm{mg} / \mathrm{g}$ of extract):

$5-100 \mu \mathrm{g} / \mathrm{ml}$ (Kędzierska et al., 2011)

Rat hepatocytes treated with adriomycin, extract of phenolic compounds from defatted milled grape seeds: $2.5-25 \mu \mathrm{g} / \mathrm{ml}$ (Valls-Belles et al., 2006$)$

Swine erythrocytes, extract from grape seeds (over 90\% condensed tannins): $7.5-30 \mu \mathrm{g} / \mathrm{ml}$ (Olas et al., 2012)

Increase of activity of antioxidant enzymes (catalase, glutathione peroxidase, superoxide dismutase) (antioxidant activity)

Human blood platelets, healthy subjects, concentration of the phenolic fraction of seed (containing phenolic compounds: 500 mg/g of extract):

$5-100 \mu \mathrm{g} / \mathrm{ml}$ (Kȩdzierska et al., 2011) 
TABLE 4 | Continued

Berries Different biomarkers of oxidative stress

Increase of activity of antioxidant enzymes (catalase, glutathione peroxidase, superoxide dismutase) (antioxidant activity)

Human blood platelets, healthy subjects, concentration of the phenolic fraction of seed (containing phenolic compounds: $500 \mathrm{mg} / \mathrm{g}$ of extract):

$5-100 \mu \mathrm{g} / \mathrm{ml}$ (Kȩdzierska et al., 2011)

Protective activity on DNA strand scission induced by hydroxyl and peroxyl radicals (antioxidant activity)

Bluescript-SH + plasmid DNA exposed to UV plus $\mathrm{H}_{2} \mathrm{O}_{2}$ or to UV plus $\mathrm{H}_{2} \mathrm{O}_{2}$ in the presence grape pomace extract (containing phenolic compounds $648 \mathrm{mg}$ gallic acid/g extract): 100-1600 $\mu \mathrm{g} / \mathrm{ml}$ (Veskouis et al., 2012)

\author{
Sea Inhibition of ROS generation (antioxidant activity) \\ buckthorn Human blood platelets, healthy subjects, concentration of the phenolic fraction of berry (dominant compounds in this fraction - flavonoids: \\ berries $\quad 214.04 \mathrm{mg} / \mathrm{g}$ ): 0.5-50 $\mu \mathrm{g} / \mathrm{ml}$ (Olas et al., 2016) \\ Inhibition of lipid peroxidation (antioxidant activity) \\ Human blood platelets and human plasma, healthy subjects, concentration of the phenolic fraction of berry (dominant compounds in this fraction - \\ flavonoids: $214.04 \mathrm{mg} / \mathrm{g}): 0.5-50 \mu \mathrm{g} / \mathrm{ml}$ (Olas et al., 2016) \\ Inhibition of protein carbonylation (antioxidant activity) \\ Human plasma, healthy subjects, concentration of the phenolic fraction of berry (dominant compounds in this fraction - flavonoids: 214.04 mg/g): \\ 0.5-50 $\mu \mathrm{g} / \mathrm{ml}$ (Olas et al., 2016)
}

\begin{tabular}{ll}
\hline & In vivo experiments \\
\cline { 2 - 3 } $\begin{array}{l}\text { Bilberries }+ \\
\text { lingonberries } \\
+ \text { black }\end{array}$ & $\begin{array}{l}\text { Increase of total antioxidant status (antioxidant activity) } \\
\text { Human plasma, healthy subjects, mix of berries (bilberries, lingonberries and black currants; } 80 \mathrm{~g} \text { of each, in the short-term) or } 100 \mathrm{~g} \text { portion of } \\
\text { deep-frozen berries (bilberries, lingonberries and black currants) daily for } 8 \text { weeks (Marniemi et al., 2000) }\end{array}$
\end{tabular}

currants

Bilberries $+\quad$ Increase of activity of antioxidant enzymes (antioxidant activity)

red grapes human plasma and erythrocytes, healthy subjects, mixture of red grapes and bilberries (80:20), 300 ml mixture daily for 2 weeks (Kuntz et al., 2014)

Increase of total antioxidant status (antioxidant activity)

Human plasma, healthy subjects, mixture of red grapes and bilberries (80:20), $300 \mathrm{ml}$ mixture daily for 2 weeks (Kuntz et al., 2014)

Inhibition of lipid peroxidation (antioxidant activity)

Human plasma and urine, healthy subjects, mixture of red grapes and bilberries (80:20), 300 ml mixture daily for 2 weeks (Kuntz et al., 2014)

Blackberries Decrease of oxidative DNA damages (antioxidant activity)

+ black Human peripheral blood mononuclear cells, healthy subjects, mixed fruit juice (red grape (57\%), blackberry juice (18\%), sour cherry juice (9\%), black

currants + c currant juice (9\%), and aronia berry juice (7\%), containing $1753 \mathrm{mg}$ of phenolic compounds/l catechin equivalents and $197.9 \mathrm{mg}$ of anthocyanins/l

sour cherries cyaniding-3-glucoside equivalents), $700 \mathrm{ml}$ juice daily for 9 weeks (Weisel et al., 2006)

+ aronia Increase of thiols (antioxidant activity)

berries + red Human blood, healthy subjects, mixed fruit juice (red grape (57\%), blackberry juice (18\%), sour cherry juice (9\%), black currant juice (9\%), and aronia

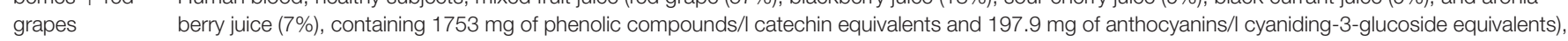
$700 \mathrm{ml}$ juice daily for 9 weeks (Weisel et al., 2006)

No changes in lipid peroxidation (antioxidant/prooxidative properties - ?)

Human plasma and urine, healthy subjects, mixed fruit juice (red grape (57\%), blackberry juice (18\%), sour cherry juice (9\%), black currant juice (9\%), and aronia berry juice (7\%), containing $1753 \mathrm{mg}$ of phenolic compounds/l catechin equivalents and $197.9 \mathrm{mg}$ of anthocyanins/l cyaniding-3-glucoside equivalents), $700 \mathrm{ml}$ juice daily for 9 weeks (Weisel et al., 2006)

\title{
Aronia berries Inhibition of lipid peroxidation (antioxidant activity)
}

Rat hepatocytes, rats treated with $\mathrm{N}$-nitrosodiethylamine (150 mg/kg) and carbon tetrachloride (2 ml/kg), aronia juice (10 ml/kg/day) for 4 weeks (Kujawska et al., 2011)

Rat plasma, liver, rates treated with carbon tetrachloride, aronia juice (5, 10, and $20 \mathrm{ml} / \mathrm{kg}$ ) daily for 2 - 4 days (Valcheva-Kuzmanova et al., 2004) Increase of activity of antioxidant enzymes (antioxidant activity)

Rat hepatocytes, rats treated with $N$-nitrosodiethylamine (150 mg/kg), aronia juice (10 ml/kg/day) for 4 weeks (Kujawska et al., 2011 )

Human hemolysates, men with blood cholesterol concentration: 205-250 mg/dl, 240 mg of anthocyanins (as Aronox) daily for 30 days (Kowalczyk et al., 2005)

No change in activity of antioxidant enzymes (antioxidant/prooxidative properties - ?)

Rat hepatocytes, rats treated with carbon tetrachloride (2 ml/kg), aronia juice (10 ml/kg/day) for 4 weeks (Kujawska et al., 2011)

Inhibition of protein carbonylation (antioxidant activity)

Rat plasma, rats treated with $N$-nitrosodiethylamine (150 mg/kg) and carbon tetrachloride (2 ml/kg), aronia juice (10 ml/kg/day) for 4 weeks (Kujawska et al., 2011)

Reduction of level of oxidized DNA (antioxidant activity)

Rat blood leukocytes, rats treated with $\mathrm{N}$-nitrosodiethylamine (150 mg/kg), aronia juice (10 ml/kg/day) for 4 weeks (Kujawska et al., 2011$)$

\section{Bayberries Inhibition of protein oxidation (antioxidant activity)}

Human plasma, young adults with features of non-alcoholic fatty liver disease, $250 \mathrm{ml}$ bayberries juice (containing $270.2 \mathrm{mg}$ phenolic compounds/100 ml and $83.5 \mathrm{mg}$ anthocyanins/100 ml), twice daily for 4 weeks (Guo et al., 2014)

Bilberries

No changes in total antioxidant status and the level of thiols (antioxidant/prooxidative properties - ?)

Human plasma, subjects at increased risk of cardiovascular disease, $330 \mathrm{ml}$ bilberry juice daily for 4 weeks (Karlsen et al., 2010)

(Continued) 
TABLE 4 | Continued

\section{Berries Different biomarkers of oxidative stress}

Blackcurrants Inhibition of lipid peroxidation (antioxidant activity)

Human plasma, healthy subjects, $250 \mathrm{ml}$ blackcurrant juice (containing $27.3 \mathrm{mg}$ phenolic compounds/100 ml and $4 \mathrm{mg}$ anthocyanins/100 ml) 4 times a day for 6 weeks (Khan et al., 2014)

Blueberries Increase of total antioxidant status (antioxidant activity)

human plasma, healthy subjects, blueberries, $100 \mathrm{~g}$ freeze-dried berries with a high-fat meal (Mazza et al., 2002)

Inhibition of lipid peroxidation (antioxidant activity)

Human plasma, chronic smokers, fresh blueberries (250 g, daily), for 3 weeks (McAnulty et al., 2015)

Inhibition of lipid peroxidation (antioxidant activity)

Human plasma, obese men and women with metabolic syndrome, blueberries (50 g freeze-dried blueberries and about $350 \mathrm{~g}$ fresh blueberries) daily for 8 weeks (Basu et al., 2010)

Increase of activity of antioxidant enzymes (antioxidant activity)

Human plasma, postmenopausal women with pre- and stage 1-hypertnsion, $22 \mathrm{~g}$ freeze-dried blueberry powder (containing 844.6 mg phenolic

compounds) daily for 8 weeks (Johnson et al., 2015)

No changes in level of thiols (antioxidant/prooxidative properties - ?)

Human plasma, healthy smokers, frozen blueberries (300 g, containing 309 mg of anthocyanins, about 856 mg of phenolic acids, 30 mg of chlorogenic acid), daily for week (Del Bo et al., 2016)

No changes in level of oxidized DNA (antioxidant/prooxidative properties - ?)

Human peripheral blood mononuclear cells, healthy smokers, frozen blueberries (300 g, containing 309 mg of anthocyanins, about 856 mg of phenolic acids, $30 \mathrm{mg}$ of chlorogenic acid), daily for week (Del Bo et al., 2016)

Cranberries Increase of total antioxidant status (antioxidant activity)

Human plasma, healthy subjects, cranberry juice (Vinson et al., 2008)

Increase of total antioxidant status (antioxidant activity)

Human plasma, healthy subjects, cranberry juice $(7 \mathrm{ml} / \mathrm{kg}$ body weight per day), for 2 weeks (Reul et al., 2005)

Inhibition of lipid peroxidation (antioxidant activity)

Human plasma, healthy subjects, cranberry juice (7 ml/kg body weight per day), for 2 weeks (Reul et al., 2005)

Human plasma, patients with the metabolic syndrome, cranberry juice (0.7 l/day, containing 0.4 mg folic acid) for 60 days (Simao et al., 2013 )

Inhibition of protein oxidation (antioxidant activity)

Human plasma, patients with the metabolic syndrome, cranberry juice (0.7 l/day, containing 0.4 mg folic acid) for 60 days (Simao et al., 2013 )

No changes in total antioxidant status, lipid peroxidation, and activity of antioxidant enzymes (antioxidant/prooxidative properties - ?)

Human blood, plasma, red blood cells and urine, healthy subjects, cranberry juice (750 ml/day, containing about $1136 \mathrm{mg}$ of phenolic compounds/l

GAE, about $2.8 \mathrm{mg}$ of anthocyanins/l), for 2 weeks (Duthie et al., 2006)

\section{Elderberries Increase of total antioxidant status (antioxidant activity)}

Human plasma, healthy subject, elderberry juice (200, 300, or $400 \mathrm{ml}$, containing 361,541 , and 722 mg anthocyanins, respectively) daily for 2 weeks (Netzel et al., 2005)

No changes in total antioxidant status (antioxidant/prooxidative properties - ?)

Human plasma, healthy subjects, elderberry juice (400 mg, containing 10\% anthocyanins) daily for 2 weeks (Murkovic et al., 2004)

\section{Grapes Inhibition of lipid peroxidation (antioxidant activity)}

Rat liver, rat received irradiation as 8 Gy whole body irradiation, $100 \mathrm{~g}$ grape seed extract (total phenolic compounds - 573.5 mg GAE/g) daily for

1 week (Cetin et al., 2008)

rat lever and kidney, lead induced oxidative stress in rats, 400 mg hydroalcoholic extract/kg daily for 30 days (Lakshmi et al., 2013 )

Cardiac tissues of rats, pancreas tissues of rats, rats were exposed to 5 Gy, grape seed extract (100 mg/kg body weight) daily for 2 weeks (Saada

et al., 2009)

Increase of total antioxidant status (antioxidant activity)

Rat plasma, pregnant rats, hydroethanolic red grapes extract, $3 \times 30 \mathrm{mg} / \mathrm{kg}$ body weight daily for 2 weeks (Muresan et al., 2010 )

Wistar rats plasma, a single dose of $300 \mathrm{mg} \mathrm{kg}^{-1}$ body weight of grape pomace extract (containing phenolic compounds $648 \mathrm{mg}$ gallic acid/g extract)

(Veskouis et al., 2012)

Increase of activity of antioxidant enzymes (antioxidant activity)

Rat liver, rat received irradiation as 8 Gy whole body irradiation, $100 \mathrm{~g}$ grape seed extract (total phenolic compounds - 573.5 mg GAE/g) daily for

1 week (Cetin et al., 2008)

Rat lever and kidney, lead induced oxidative stress in rats, 400 mg hydroalcoholic extract/kg daily for 30 days (Lakshmi et al., 2013)

Cardiac tissues of rats, pancreas tissues of rats, rats were exposed to 5 Gy, grape seed extract (100 mg/kg body weight) daily for 2 weeks (Saada

et al., 2009)

Wistar rats, gastrocnemius muscle, heart, a single dose of $300 \mathrm{mg} \mathrm{kg}^{-1}$ body weight of grape pomace extract (containing phenolic compounds

$648 \mathrm{mg}$ gallic acid/g extract) (Veskouis et al., 2012)

Increase of lipid peroxidation

Wistar rats plasma, erythrocytes, gastrocnemius muscle, heart, liver, a single dose of $300 \mathrm{mg} \mathrm{kg}^{-1}$ body weight of grape pomace extract (containing phenolic compounds $648 \mathrm{mg}$ gallic acid/g extract) (Veskouis et al., 2012)

Increase of protein carbonylation

Wistar rats plasma, erythrocytes, heart, a single dose of $300 \mathrm{mg} \mathrm{kg}^{-1}$ body weight of grape pomace extract (containing phenolic compounds 648 mg gallic acid/g extract) (Veskouis et al., 2012) 
TABLE 4 | Continued

\begin{tabular}{|c|c|}
\hline \multirow[t]{13}{*}{ Berries } & Different biomarkers of oxidative stress \\
\hline & Decrease of thiols (pro-oxidative properties) \\
\hline & $\begin{array}{l}\text { Wistar rats erythrocytes, liver, a single dose of } 300 \mathrm{mg} \mathrm{kg}^{-1} \text { body weight of grape pomace extract (containing phenolic compounds } 648 \text { mg gallic } \\
\text { acid/g extract) (Veskouis et al., 2012) }\end{array}$ \\
\hline & No change in activity of catalase (antioxidant/prooxidative properties - ?) \\
\hline & $\begin{array}{l}\text { Wistar rats erythrocytes, liver, a single dose of } 300 \mathrm{mg} \mathrm{kg}^{-1} \text { body weight of grape pomace extract (containing phenolic compounds } 648 \text { mg gallic } \\
\text { acid/g extract) (Veskouis et al., 2012) }\end{array}$ \\
\hline & No change in total antioxidant status (antioxidant/prooxidative properties - ?) \\
\hline & $\begin{array}{l}\text { Wistar rats, gastrocnemius muscle, liver, a single dose of } 300 \mathrm{mg} \mathrm{kg}^{-1} \text { body weight of grape pomace extract (containing phenolic compounds } \\
648 \mathrm{mg} \text { gallic acid/g extract) (Veskouis et al., 2012) }\end{array}$ \\
\hline & No change in protein carbonylation (antioxidant/prooxidative properties - ?) \\
\hline & $\begin{array}{l}\text { Wistar rats, gastrocnemius muscle, liver, a single dose of } 300 \mathrm{mg} \mathrm{kg}^{-1} \text { body weight of grape pomace extract (containing phenolic compounds } \\
648 \mathrm{mg} \text { gallic acid/g extract) (Veskouis et al., 2012) }\end{array}$ \\
\hline & No change in the level of thiols (antioxidant/prooxidative properties - ?) \\
\hline & $\begin{array}{l}\text { Wistar rats, gastrocnemius muscle, heart, a single dose of } 300 \mathrm{mg} \mathrm{kg}^{-1} \text { body weight of grape pomace extract (containing phenolic compounds } \\
648 \mathrm{mg} \text { gallic acid/g extract) (Veskouis et al., 2012) }\end{array}$ \\
\hline & Decrease of total antioxidant status (pro-oxidative properties) \\
\hline & $\begin{array}{l}\text { Wistar rats, gastrocnemius muscle, a single dose of } 300 \mathrm{mg} \mathrm{kg}^{-1} \text { body weight of grape pomace extract (containing phenolic compounds } 648 \text { mg } \\
\text { gallic acid/g extract) (Veskouis et al., 2012) }\end{array}$ \\
\hline
\end{tabular}

Raspberries Inhibition of lipid peroxidation (antioxidant activity)

Human urine, Barrett's esophagus patients, lyophilized raspberries [32 g (female) or $45 \mathrm{~g}$ (male)] daily (Kresty et al., 2006)

Increase of activity of antioxidant enzymes (antioxidant activity)

Human plasma, healthy subjects, $30 \mathrm{~g}$ of freeze-dried raspberries (total phenolic compounds $-1.05 \mathrm{~g} / 100 \mathrm{~g}$ of freeze dried berries) daily for

4 weeks (Lee et al., 2011)

No changes in lipid peroxidation (antioxidant/prooxidative properties - ?)

Human plasma, healthy subjects, $30 \mathrm{~g}$ of freeze-dried raspberries (total phenolic compounds $-1.05 \mathrm{~g} / 100 \mathrm{~g}$ of freeze dried berries) daily for

4 weeks (Lee et al., 2011)

Sea buckthorn Inhibition of lipid peroxidation (antioxidant activity)

berries Human plasma, healthy subjects, $300 \mathrm{ml}$ sea buckthorn juice (containing 1182 mg flavonoids/l) daily for 8 weeks (Eccleston et al., 2002)

Strawberries Inhibition of lipid peroxidation (antioxidant activity)

Human plasma, women with metabolic syndrome, 2 cups of strawberry drink per day (each cup had $25 \mathrm{~g}$ of freeze-dried strawberry powder,

containing about 1000 mg of phenolic compounds) for 4 weeks (Basu et al., 2009)

Human plasma, hyperlipidemic subjects, fresh strawberries (454 g) daily for 4 weeks (Jenkins et al., 2008)

Rat gastric, $40 \mathrm{mg} /$ day/kg body weight of strawberry crude extract for 10 days (Alavrez-Suarez et al., 2011)

Human plasma, subjects with type 2 diabetes, 2 cups of freeze-dried strawberry $(50 \mathrm{~g}$ of freeze-dried strawberry is equivalent to $500 \mathrm{~g}$ of fresh

strawberries) daily for 6 weeks (Moazen et al., 2013)

Rat plasma and liver tissue, $25 \mathrm{~g}$ strawberries daily for 2 months (Giampieri et al., 2016)

Plasma, adults with abdominal adiposity and elevated serum lipids, freeze-dried strawberries (25 - 50 g/day) for 12 weeks (Basu et al., 2014)

Increase of activity of antioxidant enzymes (antioxidant activity)

Rat gastric, $40 \mathrm{mg} / \mathrm{day} / \mathrm{kg}$ body weight of strawberry crude extract for 10 days (Alavrez-Suarez et al., 2011)

Rat plasma and liver tissue, $25 \mathrm{~g}$ strawberries daily for 2 months (Giampieri et al., 2016)

Increase of total antioxidant status (antioxidant activity)

Human plasma, subjects with type 2 diabetes, 2 cups of freeze-dried strawberry $(50 \mathrm{~g}$ of freeze-dried strawberry is equivalent to $500 \mathrm{~g}$ of fresh

strawberries) daily for 6 weeks (Moazen et al., 2013)

Human plasma, healthy subjects, daily consumption of strawberries, for 2 weeks (Tulipani et al., 2014)

Wild Increase of total antioxidant status (antioxidant activity)

blueberries Human plasma, healthy subjects, wild blueberries, $100 \mathrm{~g}$ freeze-dried berries daily for 7 days with a high-fat meal (Kay and Holub, 2002)

Reduction of level of oxidized DNA (antioxidant activity)

Human blood mononuclear cells, subjects with risk factors for cardiovascular disease, wild blueberry powder drink (one portion (25 g) containing

$0.4 \mathrm{~g}$ anthocyanins and $127.5 \mathrm{~g}$ chlorogenic acid), daily for 6 weeks (Riso et al., 2013)

No changes in total antioxidant status (antioxidant/prooxidative properties - ?)

Rat plasma, wild blueberry powder, daily for 4 or 8 weeks (Del Bo et al., 2010)

and in vivo models. This extract inhibited ROS production and DNA damage stimulated by peroxyl and hydroxyl radicals in vitro, but induced protein carbonylation, and lipid peroxidation, and decreased the level of glutathione in vivo (Table 4). Practical recommendations for the use of phenolic antioxidant should involve the use of both in vitro and in vivo experiments.

\section{CONCLUSION}

In recent years, a number of studies have examined the role of phenolic compounds in berries as antioxidants protecting against the most common diseases related to oxidative stress-driven pathologies, such as cardiovascular diseases, inflammation, cancer and neurodegenerative diseases. Berries and their 
products have been shown to play a beneficial role as antioxidants in humans in both in vitro and in vivo models using dietary supplementation with various berries (Del Bo et al., 2015), and the most potent antioxidants commonly found in berries may well be the anthocyanins. In contrast, a few papers have demonstrated that the phenolic compounds also have prooxidative activity, and berry extracts rich in phenolic compounds do not behave the same way in in vitro and in vivo models (Table 4).

However, no unwanted or toxic effects (i.e., chemical, hematological or urinary effect) have been associated with the consumption of berries or berry juices or other extracts, especially aronia berries and aronia products in vivo, and in vitro (Kulling and Rawel, 2008), which may suggest that the phenolic antioxidants found in berries are natural gifts for human health. However, the phenolic compound content of berries and berry products is not always well described, and further studies are required to determine the therapeutic doses

\section{REFERENCES}

Alavrez-Suarez, J. M., Dekanski, D., Ristic, S., Radonjic, N. V., Petronijevic, N. D., GIampieri, F., et al. (2011). Strawberry polyphenols attenuate ethanol-induced gastric lesions in rats by activation of antioxidant enzymes and attenuation of MDA increase. PLoS One 6:e25878. doi: 10.1371/journal.pone.002 5878

Andres-Lacueva, C., Shukitt-Hale, B., Galli, R. L., Jauregui, O., Lamuela-Raventos, R. M., and Joseph, J. A. (2005). Anthocyanins in aged blueberry-fed rats are found centrally and may enhance memory. Nutr. Neurosci. 8, 111-120. doi: 10.1080/10284150500078117

Bartosz, G., and Sadowska-Bartosz, I. (2015). "Oxidative, nitrosative, and chlorinative stress: biomarkers," in Studies on Psychiatric Disorders, Oxidative Stress in Applied Basic Research and Clinical Practice, eds A. Dietrich-Muszalska, V. Chauhan, and S. Grignon (New York, NY: Humana Press), 1-39.

Basu, A., Betts, N. M., Nguyen, A., Newman, E. D., Fu, D., and Lyons, T. J. (2014). Freeze-dried strawberries lower serum cholesterol and lipid peroxidation in adults with abdominal adiposity and elevated serum lipids. J. Nutr. 144, 830-837. doi: 10.3945/jn.113.188169

Basu, A., Du, M., Leyva, M. J., Sanchez, K., Betts, N. M., Wu, M., et al. (2010). Blueberries decrease cardiovascular risk factors in obese men and women with metabolic syndrome. J. Nutr. 140, 1582-1587. doi: 10.3945/jn.110.124701

Basu, A., Wilkinson, M., Penugonda, K., Simmons, B., Betts, N. M., and Lyons, T. J. (2009). Freeze-dried strawberry powder improves lipid profile and lipid peroxidation in women with metabolic syndrome: baseline and post intervention effects. Nutr. J. 8, 1-7. doi: 10.1186/1475-2891-8-43

Bisson, J., McAlpine, J. B., Friesen, J. B., Chen, S. N., Graham, J., and Pauli, G. F. (2015). Can invalid bioactive undermine natural product-based drug discover? J. Med. Chem. 59, 1671-1690. doi: 10.1021/acs.jmedchem.5b01009

Cetin, A., Kaynar, L., Kocyigit, I., Hocioglu, S. K., Saraymen, R., Ozturk, A., et al. (2008). The effect of grape seed extract on radiation-induced oxidative stress in the rat liver. Turk. J. Gastroenetrol. 19, 92-98.

Chong, M. F. F., Macdonald, R., and Lovegrove, J. A. (2010). Fruit polyphenols and CDV risk: a review of human intervention studies. Br. J. Nutr. 104, S28-S39. doi: 10.1017/S0007114510003922

Christaki, E. (2012). Hippophae rhamnoides L. (Sea Buckthorn): a potential source of nutraceuticals. Food Public Health 2, 69-72. doi: 10.1002/pca.1353

Chrubasik, C., Li, G., and Chrubasik, S. (2010). The clinical effectiveness of chokeberry: a systematic review. Phytother. Res. 24, 1107-1114. doi: 10.1002/ ptr.3226

Cotoras, M., Vinaco, H., Melo, R., Aguirre, M., Silva, E., and Mendoza, L. (2014). In vitro and in vivo evaluation of the antioxidant and prooxidant activity of phenolic compounds obtained from grape (Vitis vinifera) pomace. Molecules 19, 21154-21167. doi: 10.3390/molecules191221154 of different berry products for use in future clinical studies. Moreover, further experiments are needed to understand the beneficial effects reported so far from the mechanistic point of view. Therefore, greater attention should be paid to the development of well-controlled and high-quality clinical studies in this area.

\section{AUTHOR CONTRIBUTIONS}

The author confirms being the sole contributor of this work and approved it for publication.

\section{ACKNOWLEDGMENTS}

This work was supported grant 506/1136 from the University of Lodz.

Crecente-Campo, J., Nunes-Damaceno, M., Romero-Rodriguez, M. A., and Vazquez-Oderiz, M. L. (2012). Color, anthocyanin pigment, ascorbic acid and total phenolic compound determination in organic versus conventional strawberries (Fragaria ananassa Duch, cv Selva). J. Food Comp. Anal. 28, 23-30. doi: 10.1016/j.jfca.2012.07.004

Daskalova, E., Delchev, S., Peeva, Y., Vladimirova-Kitova, L., Kratchanova, M., Kratchanov, C., et al. (2015). Antiatherogenic and cardioprotective effects of black chokeberry (Aronia melanocarpa) juice in aging rats. Evid. Based Complement. Alternat. Med. 2015:10. doi: 10.1155/2015/717439

Del Bo, C., Martini, D., Porrini, M., Klimis-Zacas, D., and Riso, P. (2015). Berries and oxidative stress markers: an overview of human intervention studies. Food Funct. 6, 2890-2917. doi: 10.1039/c5fo00657k

Del Bo, C., Martini, D., Vendrame, S., Riso, P., Ciappellano, S., KlimisZacas, D., et al. (2010). Improvement of lymphocyte resistance against $\mathrm{H}_{2} \mathrm{O}_{2}$ induced DNA damage in Sprague-Dawley rats after eight weeks of w wild blueberry (Vaccinium angustifolium)-enriched diet. Mutat. Res. 703, 158-162. doi: 10.1016/j.mrgentox.2010.08.013

Del Bo, C., Porrini, M., Campolo, J., Parolini, M., Lanti, C., Klimis-Zacaz, D., et al. (2016). A single blueberry (Vaccinium corymbosum) portion does not affect markers of antioxidant defence and oxidative stress in healthy volunteers following cigarette smoking. Mutagenesis 31, 215-224. doi: 10.1093/mutage/ gev079

Del Bo, C., Riso, P., Brambill, A., Gardana, C., Rizzolo, A., Simonetti, P., et al. (2012). Blanching improves anthocyanin absorption from highbush blueberry (Vaccinium corymbosum L.) puree in healthy human volunteers: a pilot study. J. Agric. Food Chem. 60, 9298-9304. doi: 10.1021/jf3021333

Duba, K. S., and Fiori, L. (2015). Supercritical CO2 extraction of grape seed oil: effect of process parameters on the extraction kinetics. J. Supercrit. Fluids 98, 33-43. doi: 10.1016/j.supflu.2014.12.021

Duthie, S. J., McE Jenkinson, A., Crozier, A., Mullen, W., Pirie, L., Kyle, J., et al. (2006). The effects of cranberry juice consumption on antioxidant status and biomarkers relating to heart disease and cancer in healthy human volunteers. Eur. J. Nutr. 45, 113-122. doi: 10.1007/s00394-005-0572-9

Eberhardt, M. V., Lee, C. Y., and Liu, R. H. (2000). Nutrition - antioxidant activity of fresh apples. Nature 405, 903-904. doi: 10.1038/35016151

Eccleston, C., Baoru, Y., Tahvonem, R., Kallio, H., Rimbach, G. H., and Minihane, A. M. (2002). Effects of an antioxidant-rich juice (sea buckthorn) on risk factors for coronary heart disease in humans. J. Nutr. Biochem. 13, 346-354. doi: 10.1016/S0955-2863(02)00179-1

Erlund, I., Koli, R., Alfthan, G., Marniemi, J., Puukka, P., Mustonen, P., et al. (2008). Favorable effects of berry consumption of platelet function, blood pressure, and HDL cholesterol. Am. J. Clin. Nutr. 87, 323-331.

Fang, J. (2014a). Bioavailability of anthocyanins. Drug Metab. Rev. 46, 508-520. doi: $10.3109 / 03602532.2014 .978080$ 
Fang, J. (2014b). Some anthocyanins could be efficiently absorbed across the gastrointestinal mucosa: extensive presystemic metabolism reduces apparent bioavailability. J. Agric. Food Chem. 62, 3904-3911. doi: 10.1021/jf405 $356 \mathrm{~b}$

Fang, J. (2015). Classification of fruits based on anthocyanin types and relevance to their health effects. Nutrition 31, 1301-1306. doi: 10.1016/j.nut.2015.04.015

Ferlemi, A. V., and Lamari, F. N. (2016). Berry leaves: an alternative source of bioactive natural products of nutritional and medicinal value. Antioxidants 5 , 1-20. doi: 10.3390/antiox 5020017

Fukumoto, L. R., and Mazza, G. (2000). Assessing antioxidant and prooxidant activities of phenoic compounds. J. Agric. Food Chem. 48, 3597-3604. doi: $10.1021 / \mathrm{jf} 000220 \mathrm{w}$

Garavaglia, J., Markoski, M. N., Oliviers, A., and Marcadenti, A. (2016). Grape seed oil compounds: biological and chemical actions for health. Nutr. Metab. Insights 9, 59-64. doi: 10.4137/NMI.S32910

Garrido, J., and Borges, F. (2013). Wine and grape polyphenols - a chemical perspective. Food Res. Int. 54, 1844-1858. doi: 10.1002/jsfa.7051

Gheribi, E. (2011). Polyphenols compounds in fruits and vegetables. Med. Rodzinna 4, 111-115.

Giampieri, F., Alvarez-Suarez, J. M., Gasparrini, M., Forbes-Hernandez, T. Y., Afrin, S., Bompadre, S., et al. (2016). Strawberry consumption alleviates doxorubicin-induced toxicity by suppressing oxidative stress. Food Chem. Toxicol. 94, 128-137. doi: 10.1016/j.fct.2016.06.003

Giampieri, F., Forbes-Hernandez, T. Y., Gasparrini, M., Avarez-Suarez, J. M., Afrin, S., Bompadre, S., et al. (2015). Strawberry as a health: an evidence based review. Food Funct. 6, 1386-1398. doi: 10.1039/c5fo00147a

Giampieri, F., Tulipani, S., Alvarez-Suarez, J. M., Quiles, J. L., Mezzetti, B., and Battino, M. (2012). The strawberry: composition, nutritional quality, and impact on human health. Nutrition 28, 9-19. doi: 10.1016/j.nut.2011.08.009

Giovanelli, G., Brambilla, A., Rizzolo, A., and Sinelli, N. (2012). Effects ofblanching pre-treatment and sugar composition of the osmotic solution on physicochemical, morphological and antioxidant characteristics of osmodehydrated blueberries (Vaccinium corymbosum L.). Food Res. Int. 49, 263-271. doi: $10.1016 /$ j.foodres.2012.08.015

Giovanelli, G., Brambilla, A., and Sinelli, N. (2013). Effects of osmo-air dehydration treatments on chemical, antioxidant and morphological characteristics of blueberries. LWT Food Sci. Technol. 54, 577-584. doi: 10.1016/j.lwt.2013.06.008

Gomes-Rochette, N. F., Da Silveira Vasconcelos, M., Nabavi, S. M., Mota, E. F., Nunes-Pinheiro, D. C., Daglia, M., et al. (2016). Fruit as potent natural antioxidants and their biological effects. Curr. Pharm. Biotechnol. 17, 986-993. doi: 10.2174/1389201017666160425115401

Guo, H., Zhong, R., Liu, Y., Jiang, X., Tang, X., Li, Z., et al. (2014). Effects of bayberry juice on inflammatory and apoptotic markers in young adults with features of non-alcoholic fatty liver disease. Nutrition 30, 198-203. doi: 10.1016/ j.nut.2013.07.023

Hager, T. J., Howard, L. R., and Prior, R. L. (2008). Processing and storage effects on monomeric anthocyanins, percent polymeric color, and antioxidant capacity of processed blackberry products. J. Agric. Food Chem. 56, 689-695. doi: 10.1021/ jf071994g

Hagerman, A. E., Riedl, K. M., Jones, G. A., Sovik, K. N., Ritchared, N. T., Hartzfeld, P. W., et al. (1998). High molecular weight plant polyphenolics (tannins) as biological antioxidants. J. Agric. Food Chem. 46, 1887-1892. doi: 10.1021/ jf970975b

He, J., and Giusti, M. M. (2009). Anthocyanins: natural colorants with healthpromoting properties. Annu. Rev. Food Sci. Technol. 1, 163-187. doi: 10.1146/ annurev.food.080708.100754

Hickey, M., and King, C. (2001). The Cambridge Illustrated Glossary of Botanical Terms, 1st. Edn. Cambridge: Cambridge University Press.

Jenkins, D. J., Nguyen, T. H., Kendall, C. W., Faulkner, D. A., Bashyam, B., Kim, I. J., et al. (2008). The effect of strawberries ina cholesterol-lowering dietary portfolio. Met. Clin. Exp. 57, 1636-1644. doi: 10.1016/j.metabol.2008.07.018

Johnson, S. A., Figueroa, A., Navaei, N., Wong, A., Kalfon, R., Ormesbee, L. T., et al. (2015). Daily blueberry consumption improves blood pressure and arterial stiffness in postmenopausal women with pre- and stage 1-hypertension: a randomized, double-blind, placebo-controlled clinical trial. J. Acad. Nutr. Diet. 115, 369-377. doi: 10.1016/j.jand.2014.11.001

Kahkonen, M. P., Hopia, A. I., and Heinonen, M. (2001). Berry phenolics and their antioxidant activity. J. Agric. Food Chem. 49, 4076-4082. doi: 10.1021/jf010152t
Kalt, W., Blumberg, J. B., McDonald, J. E., Vinqvist-Tymchuk, M. R., Fillmore, S. A., Graf, B. A., et al. (2008). Identification of anthocyanins in the liver, eye, and brain of blueberry-fed pigs. J. Agric. Food Chem. 56, 705-712. doi: 10.1021/jf0719981

Kalt, W., Forney, C. F., Martin, A., and Prior, R. L. (1999). Antioxidant capacity, vitamin $\mathrm{C}$, phenolics, and anthocyanins after fresh storage of small fruits. J. Agric. Food Chem. 47, 4638-4644. doi: 10.1021/jf990266t

Kardum, N., Konic-Ristic, A., Savikin, K., Spasic, S., Stefanovic, A., Ivanisevic, J., et al. (2014). Effects of polyphenol-rich chokeberry juice on antioxidant/prooxidant status in healthy subjects. J. Med. Food 17, 869-874. doi: 10.1089/jmf.2013.0135

Karlsen, A., Paur, I., Bohn, S. K., Sakhi, A. K., Borge, G. I., Serafini, M., et al. (2010). Bilberry juice modulates plasma concentration of NF-(B related inflammatory markers in subjects at increased risk of CVD. Eur. J. Nutr. 49, 345-355. doi: 10.1007/s00394-010-0092-0

Kay, C. D., and Holub, B. J. (2002). The effect of wild blueberry (Vaccinium angustifolium) consumption on postprandial serum antioxidant status in human subjects. Br. J. Nutr. 88, 389-397. doi: 10.1079/BJN2002665

Kẹdzierska, M., Głowacki, R., Czernek, U., Szydłowska-Pazera, K., Potemski, P., Piekarski, J., et al. (2013a). Changes in plasma thiol levels induced by different phases of treatment in breast cancer; the role of commercial extract from black chokeberry. Mol. Cell. Biochem. 372, 47-55. doi: 10.1007/s11010-0121444-2

Kędzierska, M., Malinowska, J., Kontek, B., Kołodziejczyk-Czepas, J., Czernek, U., Potemski, P., et al. (2013b). Chemotherapy modulates the biological activity of breast cancer patients plasma; the protective properties of black chokeberry extract. Food Chem. Toxicol. 53, 126-132. doi: 10.1016/j.fct.2012.11.042

Kedzierska, M., Olas, B., Wachowicz, B., Glowacki, R., Bald, E., Czernek, U., et al. (2012). Effects of the commercial extract of aronia on oxidative stress in blood platelets isolated from breast cancer patients after the surgery and various phases of the chemotherapy. Fitoterapia 83, 310-317. doi: 10.1016/j.fitote.2011. 11.007

Kędzierska, M., Olas, B., Wachowicz, B., Stochmal, A., Oleszek, W., and Erler, J. (2011). Changes of platelet antioxidative enzymes during oxidative stress; the protective effect of polyphenol-rich extract from berries of Aronia melanocarpa and grape seeds. Platelets 22, 385-389. doi: 10.3109/09537104.2010. 545151

Kedzierska, M., Olas, B., Wachowicz, B., Stochmal, A., Oleszek, W., Jeziorski, A., et al. (2009). An extract from berries of Aronia melanocarpa modulates the generation of superoxide anion radicals in blood platelets from breast cancer patients. Planta Med. 75, 1405-1409. doi: 10.1055/s-0029-1185718

Kędzierska, M., Olas, B., Wachowicz, B., Stochmal, A., Oleszek, W., Jeziorski, A., et al. (2010). The nitrative and oxidative stress in blood platelets isolated from breast cancer patients; the protectory action of Aronia melanocarpa extract. Platelets 21, 541-548. doi: 10.3109/09537104.2010.492534

Khan, F., Ray, S., Craigie, A. M., Kennedy, G., Hill, A., Barton, K. L., et al. (2014). Lowering of oxidative stress improves endothelial function in healthy subjects with habitually low intake of fruit and vegetables: a randomized controlled trial of antioxidant- and polyphenol-rich blackcurrant juice. Free Radic. Biol. Med. 72, 232-237. doi: 10.1016/j.freeradbiomed.2014.04.006

Kondeva-Burdina, M., Valcheva-Kuzmanova, S., Markova, T., Mitcheva, M., and Belcheva, A. (2015). Effects of Aronia melanocarpa fruit juice on isolated rat hepatocytes. Pharmacogn. Mag. 11, S592-S597. doi: 10.4103/0973-1296.172967

Kowalczyk, E., Fijalkowski, P., Kura, M., Krzesinski, P., Blaszczyk, J., Kowalski, J., et al. (2005). The influence of anthocyanins from Aronia melanocarpa on selected parameters of oxidative stress and microelements contents in men with hypercholesterolemia. Pol. Merkur. Lekarski 19, 651-653.

Kresty, L. A., Frankel, W. L., Hammond, C. D., Baird, M. E., Mele, J. M., Stoner, G. D., et al. (2006). Transitioning from preclinical to clinical chemopreventive assessments of lyophilized black raspberries: interim results show berries modulate markers of oxidative stress in Barrett's esophagus patients. Nutr. Cancer 54, 158-156. doi: 10.1207/s15327914nc5401_15

Kristo, A. S., Klimis-Zacas, D., and Sikalidis, A. K. (2016). Protective role of dietary berries in cancer. Antioxidants 5, 1-23. doi: 10.3390/antiox5040037

Kšonžeková, P., Mariychuk, R., Eliašová, A., Mudroòová, D., Csank, T., Király, J., et al. (2016). In vitro study of biological activities of anthocyanin-rich berry extracts on porcine intestinal epithelial cells. J. Sci. Food Agric. 15, 1093-1100. doi: $10.1002 /$ jsfa. 7181 
Kujawska, M., Ignatowicz, E., Ewertowska, M., Oszmianski, J., and JodynisLibert, J. (2011). Protective effect of chokeberry on chemical-induced oxidative stress in rat. Hum. Exp. Toxicol. 30, 199-208. doi: 10.1177/096032711037 1697

Kulling, S. E., and Rawel, H. M. (2008). Chokeberry (Aronia melanocarpa) - A review on the characteristic components and potential health effects. Planta Med. 74, 1625-1634. doi: 10.1055/s-0028-1088306

Kuntz, S., Kunz, C., Herrmann, J., Borsch, C. H., Abel, G., Frohling, B., et al. (2014). Anthocyanins from fruit juices improve the antioxidant status of healthy young female volunteers without affecting anti-inflammatory parameters: results from the randomized, double-blind, placebo-controlled, cross-over ANTHONIA (ANTHOcyanins in Nutrition Investigation Allliance) study. Br. J. Nutr. 112, 925-936. doi: 10.1017/S0007114514001482

Kuntz, S., Rudloff, S., Asseburg, H., Brsch, C., Frohling, B., Unger, F., et al. (2015). Uptake and biovailability of anthocyanins and phenolic acids from grape/blueberry juice and smoothie in vitro and in vivo. Br. J. Nutr. 113, 1044-1055. doi: 10.1017/S0007114515000161

Kutlesa, Z., and Mrsic, D. B. (2016). Wine and bone health: a review. J. Bone. Miner. Metab. 34, 11-22. doi: 10.1007/s00774-015-0660-8

Lakshmi, B. V., Sudhakar, M., and Aparma, M. (2013). Protective potential of black grapes against lead induced oxidative stress in rats. Environ. Toxicol. Pharmacol. 35, 361-368. doi: 10.1016/j.etap.2013.01.008

Lall, R. K., Syed, D. N., Adhami, V. M., Khan, M. I., and Mukhtar, H. (2015). Dietary polyphenols in prevention and treatment of prostate cancer. Int. J. Mol. Sci. 16, 3350-3376. doi: 10.3390/ijms16023350

Lee, J. E., Park, E., Lee, J. E., Auh, J. H., Choi, H. K., Lee, J., et al. (2011). Effects of a Rubus coreanus Miquel supplement on plasma antioxidant capacity in healthy Korean men. Nutr. Res. Pract. 5, 429-434. doi: 10.4162/nrp.2011.5.5.429

Lee, S. G., Vance, T. M., Nam, T. G., Kim, D. O., Koo, S. I., and Chun, O. K. (2015). Contribution of anthocyanin composition to total antioxidant capacity of berries. Plant Foods Hum. Nutr. 70, 427-432. doi: 10.1007/s11130-0150514-5

Lingua, M. S., Fabani, M. P., Wunderlin, D. A., and Baroni, M. V. (2016). From grape to wine: changes in phenolic composition and its influence on antioxidant activity. Food Chem. 208, 228-238. doi: 10.1016/j.foodchem.2016.04.009

Malinowska, J., Oleszek, W., Stochmal, A., and Olas, B. (2013). The polyphenol-rich extracts from black chokeberry and grape seeds impair changes in the platelet adhesion and aggregation induced by a model of hyperhomocysteinemia. Eur. J. Nutr. 52, 1049-1057. doi: 10.1007/s00394-012-0411-8

Malinowska, P., and Olas, B. (2016). Sea buckthorn - valuable plant for health. Kosmos 2, 285-292.

Manach, C., Scalbert, A., Morand, C., Remesy, C., and Jimenez, L. (2004). Polyphenols: food sources and bioavailability. Am. J. Clin. Nutr. 79, 727-747. doi: 10.1093/ajen/79.5.727

Manach, C., Williamson, G., Morand, C., Scalbert, A., and Remesy, C. (2005). Bioavailability and bioefficacy of polyphenols in humans. Review of 97 bioavailability studies. Am. J. Clin. Nutr. 81, 230S-242S.

Marniemi, J., Hakala, P., Maki, J., and Ahotupa, M. (2000). Partial resistance of low density lipoprotein to oxidation in vivo after increased intake of berries. Nutr. Metab. Cardiovasc. Dis. 10, 331-337.

Mazza, G., Kay, C. D., Cottrell, T., and Holub, B. J. (2002). Absorption of anthocyanins from blueberries and serum antioxidant status in human subjects. J. Agric. Food Chem. 50, 7731-7737. doi: 10.1021/jf0206901

McAnulty, S. R., McAnulty, L. S., Morrow, J. D., Khardouni, D., Shooter, I., and Monk, J. (2015). Effect of daily fruit ingestion on angiotensin converting enzyme activity, blood pressure, and oxidative stress in chronic smokers. Free Radic. Res. 39, 1241-1248. doi: 10.1080/10715760500306836

McEwen, B. J. (2014). The influence of diet and nutrients on platelet function. Semin. Thromb. Hemost. 40, 214-226. doi: 10.1055/s-0034-1365839

McGhie, T. K., and Alton, M. C. (2007). The bioavailability and absorption of anthocyanins: towards a better understanding. Mol. Nutr. Food Res. 51, 702-713. doi: 10.1002/mnfr.200700092

Moazen, S., Amani, R., Homoyouni, R. A., Shahbazian, H., Ahmadi, K., and Taha Jaliali, M. (2013). Effects of freeze-dried strawberry supplementation on metabolic biomarkers of atherosclerosis in subjects with type 2 diabetes: a randomized double-blind controlled trial. Ann. Nutr. Metab. 63, 256-264. doi: $10.1159 / 000356053$
Muresan, A., Alb, C., Suciu, S., Clichici, S., Filip, A., Login, C., et al. (2010). Studies on antioxidant effects of red grapes seed extract from Vitis vinifera, Burgund Mare, Recas in pregnant rats. Acta Physiol. Hung. 97, 240-246. doi: 10.1556/APhysiol.97.2010.2.11

Murkovic, M., Abuja, P. M., Bergmann, A. R., Zirngast, A., Adam, U., WinklhoferRoob, B. M., et al. (2004). Effects of elderberry juice on fasting and postprandial serum lipids and low-density lipoprotein oxidation in healthy volunteers: a randomized, double-blind, placebo-controlled study. Eur. J. Clin. Nutr. 58, 244-249. doi: 10.1038/sj.ejen.1601773

Nassiri-Asl, M., and Hosseinzadeh, H. (2016). Review of the pharmacological effects of Vitis vinifera (Grape) and its bioactive constituents: an update. Phytother. Res. 30, 1392-1403. doi: 10.1002/ptr.5644

Nayak, B., Liu, R. H., and Tang, J. (2015). Effect of processing on phenolic antioxidnats of fruits, vegetables, and grains - a review. Crit. Rev. Food Sci. Nutr. 55, 887-919. doi: 10.1080/10408398.2011.654142

Negi, B., Kaur, R., and Dey, G. (2013). Protective effects of a novel sea buckthorn wine on oxidative stress and hipercholesterolemia. Food Funct. 4, 240-248. doi: $10.1039 / \mathrm{c} 2$ fo $30125 \mathrm{c}$

Netzel, M., Strass, G., Herbst, M., Dietrich, H., Bitsch, R., Bitsch, I., et al. (2005). The extraction and biological antioxidant activity of elderberry antioxidants in healthy humans. Food Res. Int. 38, 905-910. doi: 10.1016/j.foodres.2005. 03.010

Nicoli, M. C., Anese, M., and Parpinel, M. (1999). Influence of processing on the antioxidant properties of fruit and vegetables. Trends Food Sci. Technol. 10, 94-100. doi: 10.1016/S0924-2244(99)00023-0

Nile, S. H., and Park, S. W. (2014). Edible berries: bioactive components and their effect of human health. Nutrition 30, 134-144. doi: 10.1016/j.nut.2013.04.007

Ogah, O., Watkins, C. S., Ubi, B. E., and Oraguzie, N. C. (2014). Phenolic compounds in Rosaceae fruit and nut crops. J. Agric. Food Chem. 62, 9369-9386. doi: $10.1021 /$ jf $501574 \mathrm{q}$

Olas, B. (2016). Sea buckthorn as a source of important bioactive compounds in cardiovascular diseases. Food Chem. Toxicol. 97, 199-204. doi: 10.1016/j.fct. 2016.09.008

Olas, B. (2017). The multifunctionality of berries toward blood platelets and the role of berry phenolics in cardiovascular disorders. Platelets 28, 540-549. doi: 10.1080/09537104.2016.1235689

Olas, B., Kedzierska, M., Wachowicz, B., Stochmal, A., Oleszek, W., Jeziorski, A., et al. (2010). Effect of aronia on thiol levels in plasma of breast cancer patients. Cent. Eur. J. Biol. 5, 38-46.

Olas, B., Kontek, B., Malinowska, P., Żuchowski, J., and Stochmal, A. (2016). Hippophae rhamnoides $\mathrm{L}$. fruits reduce the oxidative stress in human blood platelets and plasma. Oxid. Med. Cell. Longev. 2016:4692486. doi: 10.1155/2016/ 4692486

Olas, B., Wachowicz, B., Stochmal, A., and Oleszek, W. (2012). The polyphenolrich extract from grape seeds inhibits platelet signaling pathways triggered by both proteolytic and non-proteolytic agonists. Platelets 23, 282-289. doi: 10.3109/09537104.2011.618562

Olas, B., Wachowicz, B., Tomczak, A., Erler, J., Stochmal, A., and Oleszek, W. (2008). Comparative anti-platelet and antioxidant properties of polyphenolrich extracts from: berries of Aronia melanocarpa, seeds of grape, bark of Yucca schidigera in vitro. Platelets 19, 70-77. doi: 10.1080/095371007017 08506

Olchowik, E., Lotkowski, K., Mavlyanov, S., Abdullajanova, N., Ionov, M., Bryszewska, M., et al. (2012). Stabilization of erythrocytes against oxidative and hypotonic stress by tannins isolated from sumac leaves (Rhus typhina L.) and grape seeds (Vitis vinifera L.). Cell. Mol. Biol. Let. 17, 333-348. doi: 10.2478/ s11658-012-0014-7

Olivas-Aguirre, F. J., Rodrigo-Garcia, J., del Martines-Ruiz, N. R., CardenasRobles, A. I., Mendoza-Diaz, S. O., Alvarez-Parrilla, E., et al. (2016). Cyanidin3-O-glucoside: physical-chemistry, foodomics and health effects. Molecules 21, 1-30. doi: 10.3390/molecules 21091264

Oszmianski, J., and Lachowicz, S. (2016). Effect of the production of dried fruits and juice from chokeberry (Aronia melanocarpa L.) on the content and antioxidative activity of bioactive compounds. Molecules 21, 1-14. doi: 10.3390/ molecules 21081098

Oszmianski, J., and Wojdylo, A. (2009). Comparative study of phenolic content and antioxidant activity of strawberry puree, clear, and cloudy juices. Eur. Food Res. Technol. 228, 623-631. doi: 10.1007/s00217-008-0971-2 
Patras, A., Brunton, N. P., O'Donnell, C., and Tiwari, B. K. (2010). Effect of thermal processing on anthocyanin stability in foods; mechanisms and kinetics of degradation. Trends Food Sci. Technol. 21, 3-11. doi: 10.1016/j.tifs.2009.07.004

Regonold, J. P., Andrews, P. K., Reeve, J. R., Carpenter-Boggs, L., and Schadt, C. W. (2010). Fruit and soil quality of organic and conventional strawberry agroecosystems. PLoS One 5:e12346. doi: 10.1371/journal.pone.0012346

Reul, G., Pomerleau, S., Couture, P., Lamarche, B., and Couillard, C. (2005). Changes in plasma antioxidant capacity and oxidized low-density lipoprotein levels in men after short-term cranberry juice consumption. Metabolism 54, 856-861. doi: 10.1016/j.metabol.2005.01.031

Riso, P., Klimis-Zacas, D., Del Bo, C., Martini, D., Campolo, J., Vendrame, S., et al. (2013). Effect of a wild blueberry (Vaccinium angustifolium) drink intervention on markers of oxidative stress, inflammation and endothelial function in humans with cardiovascular risk factors. Eur. J. Nutr. 52, 949-961. doi: 10.1007/ s00394-012-0402-9

Romani, A., Vignolini, P., Ieri, F., and Heimler, D. (2016). Polyphenols and volatile compounds in commercial chokebery (Aronia melanocarpa) products. Nat. Prod. Commun. 11, 99-102.

Rudy, S., Dziki, D., Krzykowski, A., Gawlik-Dziki, U., Polak, R., Rozilo, R., et al. (2015). Influence of pre-treatments and freeze-drying temperature on the process kinetics and selected physico-chemical properties of cranberries (Vaccinium macrocarpon Ait.). LWT Food Sci. Technol. 63, 497-503. doi: 10.1016/j.lwt.2015.03.067

Ryszawa, N., Kawczynska-Drodz, A., Pryjma, J., Czesnikiewicz-Guzik, M., Adamek-Guzik, T., Naruszewicz, M., et al. (2006). Effects of novel plant antioxidants on platelet superoxide production and aggregation in atherosclerosis. J. Physiol. Pharmacol. 57, 611-626.

Saada, H. N., Said, U. Z., Meky, N. H., and Abd El Azime, A. S. (2009). Grape seed extract Vitis vinifera protects against radiation-induced oxidative damage and metabolic disorders in rat. Phytother. Res. 23, 434-438. doi: 10.1002/ptr.2684

Samoticha, J., Wojdylo, A., and Golis, T. (2017). Phenolic composition, physicochemical properties and antioxidant activity of interspecific hybrids of grapes growing in Poland. Food Chem. 215, 263-273. doi: 10.1016/j.foodchem. 2016.07.147

Santhakumar, A. B., Stanley, R., and Singh, I. (2015). The ex vivo antiplatelet activation potential of fruit phenolic metabolite hippuric acid. Food Funct. 6, 2679-2683. doi: 10.1039/c5fo00715a

Saponidou, V. S., Margaritis, I., Siahos, N., Arsenopoulos, K., Dragatidou, E., Taitzoglou, I. A., et al. (2014). Antioxidant effect of a polyphenol-rich grape pomace extract on motility, viability and lipid peroxidation of thawed bovine spermatozoa. J. Biol. Res. 21, 1-6. doi: 10.1186/2241-5793-21-19

Scalbert, A., and Williamson, G. (2000). Dietary intake and bioavailability of polyphenols. J. Nutr. 130, 2073-2085. doi: 10.1093/jn/130.8.2073S

Simao, T. N., Lozovoy, M. A., SIamo, A. N., Oliveira, S. R., Venturini, D., Morimoto, H. K., et al. (2013). Reduced-energy cranberry juice increases folic acid and adiponectin and reduces homocysteine and oxidative stress in patients with the metabolic syndrome. Br. J. Nutr. 110, 1885-1894. doi: 10.1017/ S0007114513001207

Singh, J., and Basu, P. S. (2102). Non-nutritive bioactive compounds in pulses and their impact on human health: an overview. Food Nutr. Sci. 3, 1664-1672. doi: 10.4236/fns.2012.312218

Skrovankova, S., Sumczynski, D., Mlcek, J., Jurikova, T., and Sochor, J. (2015). Bioactive compounds and antioxidant activity in different types of berries. Int J. Mol. Sci. 16, 24673-24706. doi: 10.3390/ijms161024673

Szajdek, A., and Borowska, E. J. (2008). Bioactive compounds and healthpromoting properties of berry fruits: a review. Plant Foods Hum. Nutr. 63, 147-156. doi: 10.1007/s11130-008-0097-5

Talavera, S., Felgines, C., Texier, O., Besson, C., Mazur, A., Lamaison, J. L., et al. (2006). Bioavailability of a bilberry anthocyanin extract and its impact on plasma antioxidant capacity in rats. J. Sci. Food Agric. 86, 90-97. doi: 10.1002/ jsfa. 2327

Terahara, N. (2015). Flavonoids in foods: a review. Nat. Prod. Commun. 10, 521-528.

Toromanovic, J., Kovac-Besovic, E., Sapcainin, A., Tahirovic, I., Rimpapa, Z., Kroyer, G., et al. (2008). Urinary hippuric acid after ingestion of edible fruits Bosn. J. Basic. Med. Sci. 8, 38-43.

Tulipani, S., Armeni, T., GIampieri, F., Alvarez-Saurez, J. M., Gonzalez-Paramas, A. M., Santos-Buelga, C., et al. (2014). Strawberry intake increases blood fluid, erythrocyte and mononuclear cell defenses against oxidative challenge. Food Chem. 156, 87-93. doi: 10.1016/j.foodchem.2014.01.098

Umeno, A., Horie, M., Murotami, K., Nakajima, Y., and Yoshida, Y. (2016). Antioxidative and antidiabetic effects of natural polyphenols and isoflavones. Molecules 21, 1-15. doi: 10.3390/molecules21060708

Valcheva-Kuzmanova, S., Borisova, P., Galunska, B., Krasnaliev, I., and Belcheva, A. (2004). Hepatoprotective effect of the natural fruit from Aronia melanocarpa on carbon tetrachloride-induced acute liver damage in rats. Exp. Toxicol. Pathol. 56, 195-201. doi: 10.1016/j.etp.2004.04.012

Valcheva-Kuzmanova, S. V., Popova, P. B., Galunska, B. T., and Belcheva, A. (2006). Protective effect of Aronia melanocarpa fruit juice pretreatment in a model of carbon tetrachloride-induced hepatotoxicity in rats. Folia Med. (Plovdiv) 48, 57-62.

Valls-Belles, V., Torres, M. C., Muniz, P., Beltran, S., Martinez-Alvarez, J. R., and Codoner-Franch, P. (2006). Defatted milled grape seed protects Adriamycintreated hepatocytes against oxidative damage. Eur. J. Nutr. 45, 251-258. doi: 10.1007/s00394-006-0591-1

Veskouis, A. S., Kyparos, A., Nikolaidis, M. G., Stagos, D., Aligiannis, N., Halabalaki, M., et al. (2012). The antioxidant effects of a polyphenol-rich grape pomace extract in vitro do not correspond in vivo using exercise as an oxidant stimulus. Oxid. Med. Cell. Longev. 2012:185867. doi: 10.1155/2012/185867

Vinson, J. A., Bose, P., Proch, J., Al Kharrat, H., and Samman, N. (2008). Cranberries and cranberry products: powerful in vitro, ex vivo, and in vivo sources of antioxidants. J. Agric. Food Chem. 56, 5884-5891. doi: 10.1021/ jf073309b

Wang, L., Li, Y. M., Lei, L., Wang, X., Ma, K. Y., and Chen, Z. Y. (2015). Cranberry anthocyanin extract prolongs lifespan of fruit flies. Exp. Gerantol. 69, 189-195. doi: 10.1016/j.exger.2015.06.021

Weisel, T., Baum, M., Eisenbrand, G., Dietrich, H., Will, F., Stockis, J. P., et al. (2006). An anthocyanin/polyphenolic-rich fruit juice reduces oxidative DNA damage and increases glutathione level in healthy probands. Biotechnol. J. 1, 388-397. doi: 10.1002/biot.200600004

Wightman, J. L. D., and Henberger, R. A. (2015). Effect of grape and other berries on cardiovascular health. J. Sci. Food Agric. 95, 1584-1597. doi: 10.1002/jsfa. 6890

Wilczak, J., Kamola, D., and Jank, M. (2013). Bioavailability of polyphenolic compounds and their influence on antioxidant potential of rat plasma. Probl. Hig. Epidemiol. 94, 532-535.

Wilson, T., and Bauer, B. A. (2009). Advising consumers about dietary supplements: lessons from cranberry products. J. Diet. Suppl. 6, 377-384. doi: 10.3109/19390210903280298

Xie, L., Lee, S. G., Vance, T. M., Wang, Y., Kim, B., Lee, J. Y., et al. (2016). Bioavailability of anthocyanins and colonic polyphenol metabolites following consumption of aronia berry extract. Food Chem. 211, 860-868. doi: 10.1016/j. foodchem.2016.05.122

Yang, M., Koo, S. I., Song, W. O., and Chun, O. K. (2011). Food matrix affecting anthocynanin bioavailability: review. Curr. Med. Chem. 18, 291-300. doi: 10. 2174/092986711794088380

You, Q., Wang, B., Chen, F., Huang, Z., Wang, X., and Luo, P. G. (2011). Comparison of anthocyanins and phenolics in organically and conventionally grown blueberries in selected cultivars. Food Chem. 125, 201-208. doi: 10.1016/ j.foodchem.2010.08.063

Zafra-Stone, S., Yasmin, T., Bagchi, M., Chatterjee, A., Vinson, J. A., and Bagchi, D. (2007). Berry anthocyanins as novel antioxidants in human health and disease prevention. Mol. Nutr. Food Res. 51, 675-683. doi: 10.1002/mnfr.200700002

Conflict of Interest Statement: The author declares that the research was conducted in the absence of any commercial or financial relationships that could be construed as a potential conflict of interest.

The reviewer CT and handling Editor declared their shared affiliation.

Copyright $\odot 2018$ Olas. This is an open-access article distributed under the terms of the Creative Commons Attribution License (CC BY). The use, distribution or reproduction in other forums is permitted, provided the original author(s) and the copyright owner are credited and that the original publication in this journal is cited, in accordance with accepted academic practice. No use, distribution or reproduction is permitted which does not comply with these terms. 